\title{
THE SECRET ECONOMY OF CHARITABLE GIVING
}

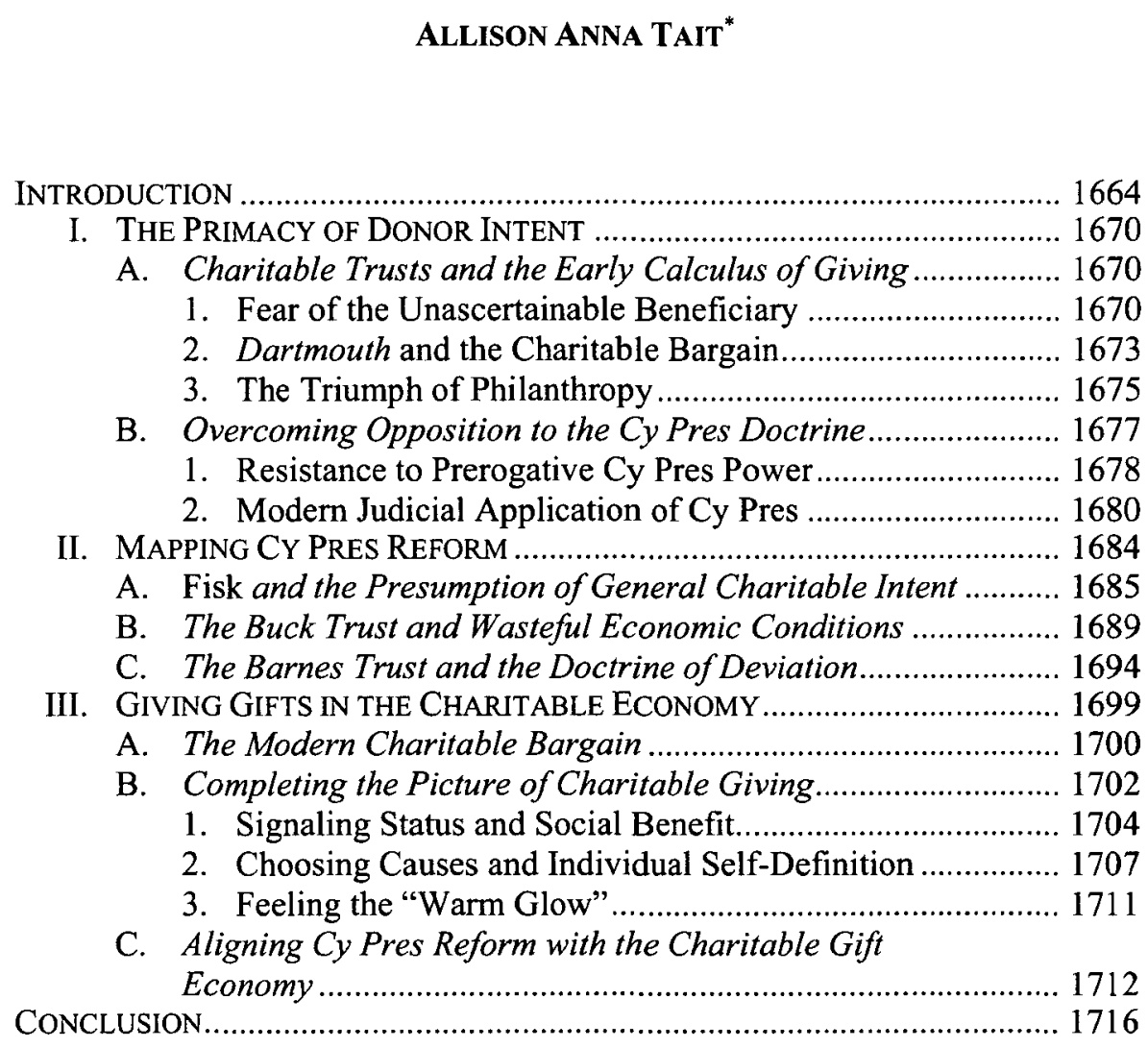

Charitable giving is big business. In 2009, the Internal Revenue Service reported close to 100,000 private foundations, almost double the number from fifteen years earlier. Some of these charitable trusts, like the Gates Foundation, are multi-billion dollar enterprises. Trust instruments and other

* Assistant Professor, University of Richmond School of Law. My great thanks for comments and conversation go to Rob Atkinson, Victoria Bjorklund, Richard Brooks, Robert Ferguson, Harvey Goldschmid, Claudia Haupt, Mary Heen, John Langbein, Philippa Loengard, James Nelson, Luke Norris, Judith Resnik, Robert Sitkoff, Peter Swords, Abigail Sussman, and participants in the Associates and Fellows workshop at Columbia Law School. My thanks go as well to Julia Mitarotondo for her excellent editorial work, and to all the editorial staff for their help. 
governing documents set forth the terms that control these gifts. Because charitable trusts can exist in perpetuity, however, changing circumstances sometimes render the terms difficult to fulfill. Courts can apply cy pres, a doctrine that allows for the modification of gift restrictions, but in the past courts have tended to apply cy pres narrowly and privilege donor intent above all other considerations. Recent reforms, however, have moved courts toward a more flexible application of the doctrine. In this Article, I analyze certain high-profile cases that have driven these reforms-including the presumption of general charitable intent, the recognition of "wasteful" as a criterion, and the deployment of deviation-and explain how these reforms represent positive change. Moreover, I provide a theoretical grounding to account for the correctness of these reforms. I argue that charitable giving should be understood as embedded in a nexus of material and social exchanges-part of the "charitable gift economy." I describe how charitable giving provides a range of benefits to donors, including both tangible tax benefits and intangible benefits such as status, social identity, and "warm glow." Based on this understanding of the charitable gift economy, courts and charities alike should embrace current reforms and seek to expand them further.

\section{INTRODUCTION}

The subject is clear. In Scandinavian civilization, and in a good number of others, exchanges and contracts take place in the form of presents; in theory these are voluntary, in reality they are given and reciprocated obligatorily.

\section{-Marcel Mauss, The Gift ${ }^{1}$}

We should often blush at our noblest deeds if the world were to see all their underlying motives.

$$
\text { -La Rochefoucauld, Maxims² }
$$

Charitable trusts and charitable giving are big business. Outright gifts to charity by individuals totaled $\$ 217.79$ billion in 2011 , in addition to $\$ 24.41$ billion in bequests made by individuals. ${ }^{3}$ It is estimated that by the year 2055 some $\$ 41$ trillion will change hands as Americans pass on accumulated wealth to the next generation. ${ }^{4}$ Much of this wealth will be transferred through the

\footnotetext{
1 Marcel Mauss, The Gift: The Form and Reason for Exchange in Archaic SOCIETIES 3 (W.D. Halls trans., 1990).

${ }^{2}$ François De La Rochefoucauld, MAXIMS 89 (Leonard Tancock trans., 1959).

${ }^{3}$ Giving USA, The ANNUAL Report on PhILANTHRopy FOR the Year 20114 (2012).

${ }^{4}$ Charitable Giving Statistics, National Philanthropic Trust, http://www.nptrust.org/philanthropic-resources/charitable-giving-statistics/
} 
creation of charitable trusts and private foundations, or through major giving by individuals to established charities. Private foundations, organized either as charitable trusts or non-profit corporations, filed 92,624 tax returns in 2009, and these foundations held $\$ 588.5$ billion in assets. ${ }^{5}$ Moreover, in the same year, these private foundations distributed $\$ 40.9$ billion for charitable purposes. ${ }^{6}$ These foundations and major gifts to charitable institutions help support colleges, hospitals, art museums, and social welfare organizations, to name only some of the organizations sustained by charitable donations.

In most major charitable giving - whether a donor creates a charitable trust, a private (non-trust) foundation, or makes a gift to an institution - the donor's charitable purpose is specified in a governing document. The trust instrument, the incorporation documents and organizational charter, or the gift agreement will detail the charitable purpose along with any relevant spending restrictions or conditions. Some large gifts are unrestricted, just as some private foundations have very broad charitable purposes, allowing the institution maximal latitude in spending. Restrictions on gifts range in specificity. Some gifts are lightly restricted, such as a fund at a museum for the purchase of art, while others are quite limited, such as a gift to fund an annual poetry prize at a particular college. Because charitable trusts and other private foundations can exist in perpetuity, and because a majority of donors indeed intend for their trusts to last in perpetuity, ${ }^{7}$ there exists a strong potential for the terms of the restricted funds and gifts to become outdated due to shifts in institutional needs, the state of medical research, and the social landscape.

In such cases-when the controlling terms of the trust outlive the need for, or the appropriateness of resource investment - the cy pres doctrine allows courts to modify the trust terms. The doctrine is set forth in section 413 of the Uniform Trust Code, which states that courts may modify the terms of a gift if the charitable purpose "becomes unlawful, impracticable, impossible to achieve, or wasteful ...." As the comment to this section mentions, cy pres is

[http://perma.cc/A28R-EJDT].

${ }^{5}$ Cynthia Belmonte, Domestic Private Foundations and Related Excise Taxes, Tax Year 2009, 32 IRS STAT. INCOME BULL. 114, 114 (Winter 2013) available at http://www.irs.gov/pub/irs-soi/13pfwinbulexcise09.pdf [http://perma.cc/5HKM-K3JJ].

${ }^{6}$ Id.

7 "The Foundation Center found in 2004 that $69.3 \%$ of foundation respondents expected their foundations to carry on in perpetuity. Nine percent did not, and $22 \%$ were undecided." Kevin Laskowski, Perpetuity Is a Long Time, NAT'L CTR. FOR FAM. PhILANTHROPY (May 15, 2008), https://www.ncfp.org/blog/2008/may-perpetuity-is-a-long-time.html [http://perma.cc/2EUJ-YYMW].

${ }^{8}$ UNIF. TRust CODE $\S 413(2010)$. The Uniform Trust Code $\S 413$ states in relevant part, "if a particular charitable purpose becomes unlawful, impracticable, impossible to achieve, or wasteful: (1) the trust does not fail, in whole or in part; (2) the trust property does not revert to the settlor or the settlor's successors in interest; and (3) the court may apply cy pres to modify or terminate the trust by directing that the trust property be applied or distributed, in whole or in part, in a manner consistent with the settlor's charitable purposes." Id. The 
applied not only to modify the terms of charitable trusts, but also to modify any donor restrictions placed on charitable gifts. ${ }^{9}$ Furthermore, pursuant to both the Uniform Trust Code and the Uniform Prudent Management of Institutional Funds Act ("UPMIFA"), cy pres is applicable to restricted funds held by nonprofit corporations as well as charitable trusts. ${ }^{10}$ Historically, courts have tended to apply cy pres both narrowly and infrequently, manifesting a reluctance to overturn donor intent. More recently, however, a number of highprofile cases with deeply contested results-including cases involving Fisk University, the Buck Trust, and the Barnes Foundation-have pushed questions concerning cy pres into public discourse, and propelled doctrinal reform. ${ }^{11}$

In this Article, I discuss changes to the Uniform Trust Code-including the presumption of general charitable intent, the recognition of "wasteful[ness]" as a criterion for cy pres application, and the deployment of equitable deviationand demonstrate their utility. These reforms have answered some longstanding critiques of the cy pres doctrine; ${ }^{12}$ but critics have also argued that the reforms are too cautious, or even harmful. ${ }^{13}$ I maintain that the recent cy pres reforms

comment to this section further states that "[t]he doctrine of cy pres is applied not only to trusts, but also to other types of charitable dispositions, including those to charitable corporations. This section does not control dispositions made in nontrust form. However, in formulating rules for such dispositions, the courts often refer to the principles governing charitable trusts, which would include this Code." Id. $\S 413 \mathrm{cmt}$.

${ }^{9}$ Id. $\S 413 \mathrm{cmt}$.

${ }^{10} \mathrm{Id}$; U UNIF. PRUDENT MGMT. OF InSTITUTIONAL FUNDS ACT prefatory note at 4 (2006) ("UPMIFA clarifies that the doctrines of cy pres and deviation apply to funds held by nonprofit corporations as well as to funds held by charitable trusts. Courts have applied trust law rules to nonprofit corporations in the past, but the Drafting Committee believed that statutory authority for applying these principles to nonprofit corporations would be helpful.").

11 See infra notes 123-179, 200-228 and accompanying text.

12 See Rob Atkinson, Reforming Cy Pres Reform, 44 Hastings L.J. 1111, 1115 (1993) ("Proposals to increase the flexibility of cy pres thus result in an unstable compromise between absolute dead hand control and unfettered judicial discretion."); C. Ronald Chester, Cy Pres: A Promise Unfulfilled, 54 IND. L.J. 407, 417 (1979) (explaining that while some expansion of cy pres doctrine has been achieved, much less progress has been made to cy pres's general charitable intent requirement).

${ }^{13}$ Some scholars believe that the reform efforts have not been sufficient to modernize an outdated doctrine. See, e.g., Rob Atkinson, The Low Road to Cy Pres Reform: Principled Practice to Remove Dead Hand Control of Charitable Assets, 58 CASE W. RES. L. REV. 97, 97 (2007) (stating that calls for reform, "for all their merit, have gone virtually unheeded"); see also Melanie B. Leslie, Time To Sever The Dead Hand: Fisk University and the Cost of the Cy Pres Doctrine, 31 CARDozo ARTS \& ENT. L.J. 1, 5 (2012). Critics of the reform measures also exist. See Alberto B. Lopez, A Revaluation of Cy Pres Redux, 78 U. CIN. L. REV. 1307, 1312 (2010) ("UTC section 413 tilts the theoretical balance of interests associated with cy pres too far toward the public interest . . . ."); Eric G. Pearson, Reforming the Reform of the Cy Pres Doctrine: A Proposal to Protect Testator 
represent positive-though unappreciated-change. The changes adopted by the Uniform Trust Code, which has yet to be adopted by all states, ${ }^{14}$ have the potential to reduce litigation time and cost in cy pres cases. These changes likewise have the potential to benefit both nonprofit institutions and the public by increasing institutional access to restricted gift funds.

Moreover, I put forth a theory that fully accounts for the correctness of these and additional reforms. The lessening of dead-hand control has justified the traditional availability of cy pres modifications as well as the recent Uniform Trust Code changes that provide new latitude to nonprofit institutions. This theory is grounded in the concepts of economic efficiency (that is, enabling the efficient use of assets) and, less often, intergenerational fairness. ${ }^{15} \mathrm{Cy}$ pres facilitates anti-dead-hand policy by allowing for the modification or removal of value-impairing terms. Restraining dead-hand control remains an important justification for allowing cy pres and granting flexibility. Anti-dead-hand control, however, provides a theoretical grounding for cy pres that addresses only extrinsic factors, such as changed circumstances.

I propose, instead, a theory that justifies cy pres modification of charitable gifts based on factors intrinsic to charitable gifts and puts forth the idea that charitable gifts represent a particular type of property requiring special treatment. This theory rests on the concept of charitable giving as an intricate constellation of multi-part exchanges-what I call the charitable gift economy. The theory of the charitable gift economy explains how and why charitable

Intent, 90 MARQ. L. REV. 127, 127 (2006); Chris Abbinante, Comment, Protecting "Donor Intent" in Charitable Foundations: Wayward Trusteeship and the Barnes Foundation, 145 U. PENN. L. REV. 665, 668 (1997) (arguing that society should, but the legal system should not, permit deviations from donors' wishes). For a comparative perspective, see Peter Luxton, Cy Près and the Ghost of Things that Might Have Been, 47 ConV. \& Prop. Law. 107, $116(1983)$.

${ }^{14}$ Currently, thirty-one states and the District of Columbia have adopted the Uniform Trust Code. Legislative Fact Sheet-Trust Code, UNIFORM LAW COMMISSION, http://www.uniformlaws,org/LegislativeFactSheet.aspx?title=Trust\%20Code

[http://perma.cc/SX5W-F485] (listing jurisdictions that have adopted the Uniform Trust Code: Alabama, Arizona, Arkansas, District of Columbia, Florida, Kansas, Kentucky, Maine, Maryland, Massachusetts, Michigan, Minnesota, Mississippi, Missouri, Montana, Nebraska, New Hampshire, New Jersey, New Mexico, North Carolina, North Dakota, Ohio, Oregon, Pennsylvania, South Carolina, Tennessee, Utah, Vermont, Virginia, West Virginia, Wisconsin, and Wyoming).

${ }^{15}$ Lewis M. Simes, Public Policy and the Dead Hand 127 (1955). See also John H. Langbein, Mandatory Rules in the Law of Trusts, 98 Nw. U. L. REv. 1105, 1110 n.33 (2004) ("Most discussion of the anti-dead-hand policy has centered on the rule against perpetuities and has emphasized the need to promote alienability of land. Simes rightly pointed out that this rationale does not explain why the rule should apply to trusts in which the trustee has the power of sale.... Simes's alternative justification, 'strik[ing] a fair balance between the desires of members of the present [and] succeeding generations,' . . is a slogan, not an explanation."); John H. Langbein, Burn the Rembrandt? Trust Law's Limits on the Settlor's Power to Direct Investments, 90 B.U. L. REV. 375, 378 (2010). 
gifts have particular idiosyncratic property values by providing a frame for better understanding charitable giving as a socially significant practice that creates various and multiple meanings within a gift. Like the anti-dead-hand theory, this theory ultimately provides justification for increased flexibility in cy pres doctrine.

Anthropologists and sociologists have long believed that gifts are a strong form of currency in an economy driven by non-market transactions. Marcel Mauss, in his seminal study of Polynesian and other cultures, demonstrated the ways in which gifts have been deployed to create an economy of transfers, services, and obligations governed by social norms and customary behavior. ${ }^{16}$ Economists have likewise been drawn to the question of gift giving, trying to understand what motivates individuals to engage in the practice of gifting since it generally contravenes individuals' economic interests. Thorstein Veblen put forth foundational theories about conspicuous consumption and leisure, positing that individuals spend and give for reasons related to social status and class expectations. ${ }^{17}$ Building on these theories of social exchange, Eric Posner has concluded that gifts are motivated by altruism, status building, and trust creation, and has observed that "[f]requently ... transfers that are called 'gifts' do call for a return transfer, if only implicitly or by convention ...." Carol Rose, alluding to the norm of reciprocity, has asked: "Does anybody really ever give anything away?"19

Sociologists have added to the conversation by exporting the debate about gift-as-exchange into the realm of philanthropy. They have examined the various reasons for which donors give, paying attention to the complicated cultural networks that charitable gifts create and maintain..$^{20}$ Scholars in

${ }^{16}$ Robert J. Shiller, discussing the importance of retaining the charitable deduction, has noted that "[g]ift-giving has a long history. Marcel Mauss, in 'The Gift' in 1924, and Karl Polanyi, in 'The Great Transformation' in 1944, argue that reciprocal gift-giving - giving with some hope of recognition or response-has pervaded healthy human society from its Neolithic beginnings." Robert J. Shiller, Please Don't Mess With the Charitable Deduction, N.Y. TIMES, Dec. 15, 2012, at BU7.

17 See Thorstein Veblen, The Theory of the Leisure Class 41 -79 (1953).

18 Eric A. Posner, Altruism, Status, and Trust in the Law of Gifts and Gratuitous Promises, 1997 WIS. L. REV. 567, 569.

${ }^{19}$ Carol M. Rose, Giving, Trading, Thieving, and Trusting: How and Why Gifts Become Exchanges, and (More Importantly) Vice Versa, 44 FLA. L. REV. 295, 295 (1992).

${ }^{20}$ See, e.g., Francie Ostrower, Why the Wealthy Give: The Culture of Elite PHILANTHROPY 32 (1995) ("It is important to note that among elites, involvement with organizations is often tied to family identity and to the social networks in which the donor participates."). See also Emily Barman, An Institutional Approach to Donor Control: From Dyadic Ties to a Field-Level Analysis, 112 AM. J. Soc. 1416, 1422 n.3 (2007) (explaining that communities centered around class, geography, religion, race and ethnicity "entail social norms and networks that produce particular modes of donor behavior"); Susan A. Ostrander, The Growth of Donor Control: Revisiting the Social Relations of Philanthropy, 36 NONPROFIT \& VOLUNTARY SECTOR Q. 356, 361 (2007) (explaining that today donors may 
philanthropy studies and fundraising experts have scrutinized the factors that motivate individual giving, particularly in order to craft better fundraising strategies. ${ }^{21}$ The concept of the charitable gift as a part of a charitable gift economy has not, however, been discussed in legal scholarship concerning trust principles and the regulation of charitable gifts. This omission is striking because charitable gifts reveal and exemplify the gift economy at work. Furthermore, the charitable gift economy is significant because it encompasses not just the micro connections of family, friends, and colleagues (conventional parties in non-charitable giving exchanges), but also macro connections between individuals and institutions. My contribution with this Article, therefore, is to develop and apply the concept of the charitable gift economy to charitable giving law, in order to help reimagine the base assumptions inherent in charitable giving regulation and cy pres rules.

This Article proceeds in three parts. In Part I, I describe the evolution of charitable trust regulation, charity law, and the cy pres doctrine. I pay particular attention to how charitable giving law developed such that donor intent became the lodestar of judicial analysis. Part II of the Article contains an analysis of recent cy pres cases that have generated commentary and driven reform. These cases exemplify some of the problems with cy pres doctrine and demonstrate the ways in which the reforms put forth in the Uniform Trust Code could have or already have benefitted plaintiff institutions. In Part III, I develop the idea of the charitable gift economy, drawing on established concepts of the gift economy in other fields, and discuss the nexus of exchanges that constitutes this charitable gift economy. I detail the benefits, both tangible and intangible, that flow to charitable donors, and clarify why donor control should be restricted based on the robust nature of these benefits. I conclude that in light of the realities of this charitable gift economy, the Uniform Trust Code reforms are appropriate, and donor intent should be even less controlling and increasingly time-limited moving forward.

give based on "their own "philanthropic agendas"" which "probably have more to do with 'personal considerations"" including "family traditions of giving ... and giving because one is asked to do so by members of one's social or professional or business networks"); Susan A. Ostrander \& Paul G. Schervish, Giving and Getting: Philanthropy as a Social Relation, in CRITICAL Issues IN AMERICAN PhILANThropy: StRengthenING TheORY AND Practice 67,70 (1990) ("[P]hilanthropy is a particular type of social relation that may occur in government and corporate settings, and it most certainly occurs in families and neighborhoods.").

21 See, e.g., Peter Frumkin, Strategic Giving: The Art and Science of PHILANTHROPY 3 (2006) ("I diagnose the core problems in the world of giving today, offer a framework for reconstructing practice ... and explore how to promote a more vital philanthropic sector."). See also Joan Mount, Why Donors Give, 7 NonProfit MgmT. \& LEADERSHIP 3, 5 (1996) ("This article examines motives that lie behind personal philanthropy ... and why donors give the amounts they do. Extrapolating from these findings, I . . suggest some of the implications . . . for fundraisers."). 


\section{THE PRIMACY OF DONOR INTENT}

Traditionally, for a number of reasons, courts have hewed very closely to donor intent. In this Part, I analyze the historical development of the law regulating charitable trusts in America and describe the various factors that led to the strict judicial adherence to donor intent. I then describe the history of the cy pres doctrine and its close relationship to the development of charitable trust law. I also describe the modern cy pres doctrine both before and after recent Uniform Trust Code reforms.

\section{A. Charitable Trusts and the Early Calculus of Giving}

In early American courts, misunderstandings concerning the legal status of charitable trusts and Chancery's equitable jurisdiction over these trusts were common among both judges and lawyers. In particular, confusion persisted concerning the ability of an individual to bequeath a charitable gift to an unascertainable beneficiary-such as an unincorporated association. At the same time that state courts were grappling with this question, Justice John Marshall answered a different legal question and put forth an early and influential theory of charitable giving in Trustees of Dartmouth College v. Woodward, ${ }^{22}$ grounded in the importance of donor intent. ${ }^{23}$ Marshall's theory of great men making charitable gifts to build a legacy was reinforced by subsequent shifts in the economic landscape and the emergence of major philanthropists.

\section{Fear of the Unascertainable Beneficiary}

In the wake of the Revolution and eager to clear the statute books of English influence, "state legislatures and the courts began to test every point of English law."24 The resulting legal confusion produced a Virginia case concerning the validity of a bequest on the U.S. Supreme Court's docket in 1819. The case, Trustees of the Philadelphia Baptist Association v. Hart's Executors, ${ }^{25}$ turned on the question of whether an unincorporated association could be the legal recipient or beneficiary of the deceased Hart's intended charitable trust. ${ }^{26}$ At issue was the status of such a bequest before the enactment of the Statute of

2217 U.S. (4 Wheat.) 518 (1819).

${ }^{23}$ Id. at 518 ("An act of the State legislature of New-Hampshire, altering the charter . . . is an act impairing the obligation of the charter, and is unconstitutional and void.").

${ }^{24}$ Howard S. Miller, The Legal Foundations of American Philanthropy: 1776$1844,10(1961)$. States modified and repealed English statutes to varying degrees, and some states, like Virginia, enacted legislation that effectuated the wholesale repeal of English law. Id. ("An act of December 27, 1792, titled 'An Act Repealing under Certain Restrictions, all Statutes or Acts of Parliament of Great Britain, heretofore in Force within this Commonwealth,' placed Virginia formally beyond the reach of English jurisprudence.").

${ }^{25} 17$ U.S. (4 Wheat.) 1 (1819), overruled by Vidal v. Girard's Ex'rs, 43 U.S. (2 How.) 127 (1844).

${ }^{26} I d$. at 28 . 
Charitable Uses in England, ${ }^{27}$ which sustained bequests to unincorporated associations. ${ }^{28}$ The question was important because, as Justice Story observed, "the statute of Elizabeth not being in force in Virginia... it becomes a material inquiry, how far the jurisdiction and doctrines of the court of chancery respecting charitable uses depends upon that statute, and whether, independent of it, the present donation can be upheld." 29 The Court held that there was no precedent outside of the repealed statute for supporting the gift, and the bequest failed.

It was not until 1844, and the publication of previously unavailable English Chancery reports, that the Court overturned Hart and established support for charitable trusts in Vidal v. Girard's Executors. ${ }^{30}$ Despite the ruling in the Girard case, however, the lack of ascertainable beneficiaries continued to cause bequests to fail in a number of states. ${ }^{31}$ For example, in the case of

27 Statute of Charitable Uses, 1601, 43 Eliz., c. 4 (Eng.). The Statute of Charitable Uses was enacted in 1601 , a reform driven by the desire to "efficiently protect the use of charitable assets, and [cultivate] the ethos of . . . such giving," such that "the middle and upper middle classes, particularly the merchant gentry, might increase their support towards ends that the State approved." James J. Fishman, The Political Use of Private Benevolence: The Statute of Charitable Uses, PACE UNIVERSITY (Apr. 23, 2008), http://digitalcommons.pace.edu/cgi/viewcontent.cgi?article $=1486 \&$ context=lawfaculty [http://perma.cc/E8KX-YPBA]. The Statute "is famous for providing a legal definition of charitable purpose and is the starting point for the modern law of charity." $I d$.

28 Preachers' Aid Soc'y of the Me. Conference of the Methodist Episcopal Church v. Rich, 45 Me. 552, 552 (1858) ("A bequest to charitable uses, to an unincorporated society may be enforced, by virtue of the statute of 43 Eliz. c. 4 ....").

29 Trs. of the Phila. Baptist Assoc. v. Hart's Ex'rs, 17 U.S. (4 Wheat.) 1 (1819) (Story, J., concurring), overruled by Vidal, 43 U.S. (2 How.) 127.

30 Vidal, 43 U.S. (2 How.) at 196 ("But very strong additional light has been thrown upon this subject by the recent publication of the Commissioners on the public Records in England, which contain a very curious and interesting collection of the chancery records in the reign of Queen Elizabeth, and in the earlier reigns."). For a discussion of the case and its cultural resonance, see Robert A. Ferguson, The Girard Will Case: Charity and Inheritance in the City of Brotherly Love, in PHILANTHROPY AND AMERICAN SOCIETY: SELECTED PAPERS 1 (Jack Salzman ed., 1987).

31 Edith Fisch remarks that "it was a case of locking the barn door after the horse had been stolen. ... [T] he error became so firmly entrenched in . . . law that the Girard decision failed to remedy the situation." EDITH L. FISCH, THE CY PRES DoctRINE IN THE UNITED STATES 12-13 (1950). Following Girard, a small set of cases upheld charitable trusts on the grounds that English common law supported them. See, e.g., Williams v. Williams, 8 N.Y. 525,542 (1853) ("I have come to the conclusion that the law of charities was at an indefinite but early period in English judicial history, engrafted upon the common law . . .."). For a description of the approximately half-dozen cases in New York that followed this analysis, see Stanley N. Katz, Barry Sullivan \& C. Paul Beach, Legal Change and Legal Autonomy: Charitable Trusts in New York, 1777-1893, 3 LAw \& HiST. REV. 51, 67-68 (1985). Once equity and law merged in New York, this line of cases was overturned. Id. at 72 (stating that following the "abolition of the Court of Chancery" New York's Court of Appeals 
Bascom v. Albertson, ${ }^{32}$ the high court in New York ruled that charitable trusts created through bequests with no ascertainable beneficiaries were void under state law. ${ }^{33}$ New York's settled policy, the court stated, was rather to "encourage donations and endowments for educational, religious and charitable purposes, by providing for the administration of such funds through organized and responsible agencies, sanctioned by legislative authority, and subject to legislative regulation and control." 34

The most notorious case was that of Samuel Tilden, a corporate lawyer turned politician who became the governor of New York and was the Democratic candidate for the U.S. Presidency in 1876. Tilden left a bequest directing his executors and trustees to procure an act of incorporation for "an institution to be known as the 'Tilden Trust' with capacity to establish and maintain a free library and reading-room in the city of New York, and to promote such scientific and educational objects as my said executors and trustees may more particularly designate. ${ }^{35}$ The court concluded that the trust was void and, because the intention to promote science and education was unacceptably indefinite, the bequest to the library failed as well. ${ }^{36}$ The court asked: "Can it be seriously claimed that there is any duty resting on [the trustees] to establish a library in the city of New York?" 37

This result in the Tilden case garnered remarkable attention both locally and nationally, and the bulk of the criticism derived from the fact that the court's hostility to charitable trusts was overriding donor intent. While the case was pending, the New York Times published an article that stated optimistically, "[t]he courts will undoubtedly consider the purpose and intent of the testator, and whether by the creation of the Tilden Trust that purpose and intent can be carried out...."38 After the decision, James Barr Ames observed that "the

abandoned "the favor developed for charitable trusts in the old Court of Chancery"). For a short overview of the development of charitable trusts, see MARION R. FREMONT-SMITH, Governing NonProfit Organizations: FEderal and State LaW and REgulation 44-48 (2008).

3234 N.Y. 584 (1866).

${ }^{33} \mathrm{Id}$. at 584.

${ }^{34}$ Id. Like Virginia, New York had repealed the Statute of Charitable Uses. Id. Moreover, addressing the Girard argument that early Chancery cases demonstrated valid bequests to unascertainable beneficiaries, the court stated:

The legislature of this State could not fail to see that the earlier English system of charity, which was superseded and displaced by the statute of Elizabeth, was fragmentary and disjointed; that it was obscure in its origin, incongruous in its theory, and disastrous in its tendency; that it had been discarded as an excrescence upon the common law....

Id. at 605.

${ }^{35}$ Tilden v. Green, 28 N.E. 880, 881 (N.Y. 1891).

${ }^{36} \mathrm{Id}$. at $888-89$.

${ }^{37} \mathrm{Id}$. at 887 .

${ }^{38}$ The Tilden Trust Corporation, N.Y. TIMES, Mar. 29, 1887, at 4. 
beneficent purpose of the testator was unmistakably expressed in a will executed with all due formalities" and that the court's decision was a "deplorable disappointment of the testator's will." 39 Because of great public dissatisfaction, the New York legislature passed the Tilden Act in 1893, which authorized charitable trusts and, more particularly, bequests made to unascertainable beneficiaries for charitable purposes ${ }^{40}$ This legislation was a turning point for the regulation of charitable trusts and marked the legal embrace of charitable trusts as a vehicle for philanthropic giving.

\section{Dartmouth and the Charitable Bargain}

Despite judicial misgivings about the nature of charitable trusts, support did exist for charitable giving when done through the proper channels. In fact, an influential judicial theory in support of charitable giving, set forth in Dartmouth, was beginning to take shape during this same period. ${ }^{41}$ Decided in the same term as the Hart case, Dartmouth addressed the New Hampshire legislature's ability to modify Dartmouth College's charter through legislation without the express consent of the college trustees. The charter was, Marshall remarked, "a contract for the security and disposition of property"42 and ample consideration existed in the grant of "perpetual application of the fund to its object." ${ }^{43}$ Marshall described the contract entered into between a donor and the State: "[c]haritable, or public spirited individuals ... apply to the government, state their beneficent object, and offer to advance the money necessary for its accomplishment, provided the government will confer on the instrument which is to execute their designs the capacity to execute them."44

The charitable bargain, accordingly, consisted of individuals dedicating resources to public benefit in return for a way to implement the charitable vision of the individual. Adherence to donor restrictions was both an incentive and the reward for charitable giving. Marshall observed:

\footnotetext{
39 J. B. Ames, The Failure of the "Tilden Trust," 5 HARV. L. REV. 389, 389 (1892).

40 The Act stated that:

No gift, grant, bequest or devise to religious, educational, charitable, or benevolent uses, which shall, in other respects be valid under the laws of this state, shall or be deemed invalid by reason of the indefiniteness or uncertainty of the persons designated as the beneficiaries thereunder in the instrument creating the same.
}

Tilden Act, 1893 N.Y. Laws 1748 (codified as amended at N.Y. REAL ProP. LaW $\S 113$, N.Y. PERS. PROP. LAW § 12).

${ }^{41}$ Trs. of Dartmouth Coll. v. Woodward, 17 U.S. (4 Wheat.) 518, 518 (1819) ("The charter granted by the British crown to the trustees of Dartmouth College . . . is a contract within the meaning of ... the constitution of the United States .....").

$42 I d$. at 644 .

43 Id. at 642 .

44 Id. at 637-38. Justice Story, concurring in the opinion, also remarked that there was an implied contract between the corporation and the beneficiaries "that [the corporation] would administer his bounty according to the terms, and for the objects stipulated in the charter." Id. at 690 (Story, J., concurring). 
It requires no very critical examination of the human mind to enable us to determine, that one great inducement to these gifts is the conviction felt by the giver, that the disposition he makes of them is immutable... A All such gifts are made in the pleasing, perhaps delusive hope, that the charity will flow forever in the channel which the givers have marked out for it. ${ }^{45}$

In this calculus of giving, the donor was motivated by altruism and the desire to further social welfare and the public good. Because the donor received no benefit other than the ability to impose his will by restricting a gift in perpetuity, the organization owed it to the donor to execute his design as intended. The charitable bargain was an exchange of resources for immortality.

The Dartmouth case, therefore, helped to foster certain judicial values and traced an outline for the future of charity law. ${ }^{46}$ In cases that followed, courts cited Dartmouth a number of times concerning the charitable bargain. City of Louisville v. President \& Trustees of the University of Louisville ${ }^{47}$ turned on similar questions of the city's rights with respect to University governance after the city had made a major gift to the University ${ }^{48}$ Ruling in favor of the University and citing to Dartmouth, the Chief Justice of the Kentucky court stated, "there is certainly a contract between the donors and the donee. And as the donors parted with their property under the inducements of the charter promising a continuance of the corporation, the faith of the state was pledged to them ...."49 Likewise, relying on Dartmouth, the court in one of the leading New York decisions supporting charitable trusts observed that charitable giving "was a contract between the government and the donors, one of the terms of which was, that the lands should be held by the corporation in perpetuity to promote the pious and charitable objects of its institution." ${ }^{50}$ An

45 Id. at 647.

46 Writing about the Dartmouth case, Mark D. McGarvie has remarked, "[t]he beginning of philanthropic organizations occurred not with the funding of the large trusts at the turn of the twentieth century, but in the creation of the legal model for philanthropic pursuits during the early republic." Mark D. McGarvie, The Dartmouth College Case and the Legal Design of Civil Society, in CHARITY, PHILANTHROPY, AND Civility IN AMERICAN History 91, 105 (Lawrence J. Friedman \& Mark D. McGarvie eds., 2003). McGarvie suggests that the Dartmouth case moved philanthropy away from a community model present in the colonial period "by demanding formal legal structures for religious and philanthropic organizations." Id.

4754 Ky. (15 B. Mon.) 642 (1855).

$48 I d$. at 666 (stating that the case's two principal questions are whether the University's original charter is constitutionally protected as a contract and, if it is a contract, whether the city's charter violates the original University charter).

49 Id. at 686.

50 Williams v. Williams, 8 N.Y. 525, 534 (1853). "Subsequent decisions, however, repeatedly attacked the Williams case, and its scope was narrowed until it was virtually impossible to formulate a charitable trust of personalty that would be held valid." Edith $\mathrm{L}$. Fisch, American Acceptance of Charitable Trusts, 28 NOTRE DAME LAw. 219, 223 (1953) (footnote omitted). 
Indiana court likewise concluded that the state legislature could not pass any law that would impair the contractual obligations between an incorporated charitable organization and its donors. ${ }^{51}$ Courts reaffirmed and propagated the legal notion set forth in Dartmouth that charitable organizations owed donors adherence to their intent as a matter of contract, ultimately helping to justify support for both charitable giving and the primacy of donor intent.

\section{The Triumph of Philanthropy}

Seismic changes in wealth holding and philanthropy at the end of the nineteenth century helped to both reform the law of charitable trusts and reaffirm the importance of donor intent. By the end of the nineteenth century, changed economic conditions and national markets had created a class of newly minted millionaires. ${ }^{52}$ In 1892, the New York Tribune counted and published the names of 4047 millionaires; by 1916, there were 40,000 millionaires (including John D. Rockefeller and Henry Ford, who were actually billionaires). ${ }^{53}$ A few months after the list was published in 1916, another article, American Millionaires and Their Public Gifts, was published, and "[t]he author observed that it would be interesting if the millionaires enumerated by the Tribune could be separated into givers and non-givers." 54 Shortly after that, "George J. Hagar, a member of the staff of Appleton's Annual Cyclopaedia, began in 1893 to collect figures on gifts and bequests ... for religious, charitable and educational purposes." 55

Charitable giving brought public status and created public personae in a new and spectacular way. Philanthropy was biography, and wealthy individuals sought to make their mark on the social landscape through charitable giving. In

51 Edwards v. Jagers, 19 Ind. 407, 415 (1862) ("[T]here was an implied contract, between the donor and the corporation, that the property should be used only for the purposes indicated by the charter.").

52 According to Robert A. Gross, this development in giving marked a turn from charity ("concrete and individual") to philanthropy ("abstract and institutional"). See Robert A. Gross, Giving in America: From Charity to Philanthropy, in CHARITY, PHILANTHROPY, AND Civility IN AMERICAN History, supra note 46, at 31.

53 Olivier Zunz, Philanthropy in AMERICA: A History 8 (2011).

The list was arranged state by state, city by city. The kind of economic activity thought to be the major factor in the creation of each fortune was indicated. The Tribune's financial editor claimed to have consulted 1,500 merchants, bankers, commercial agents, lawyers, surrogates of counties, trustees and other citizens all over the country in a position to know the facts.

Merle Curti, Judith Green \& Roderick Nash, Anatomy of Giving: Millionaires in the Late 19th Century, 15 AM. Q. 416, 418 (1963).

54 Curti et al., supra note 53, at 419.

55 Id. at 420 . Hagar excluded all gifts under $\$ 5000$. "The result of the first year's quest," Hagar later wrote, "was such a grand tribute to the humanity of the American men and women' that he continued to make similar investigations through the year 1903." Id. For his results, see $i d$. at 421 (Table I). 
this context of new wealth, "philanthropic projects were acts of generosity and hubris on a scale never before entertained. The new rich felt free to both envision and fashion the common good, and they did so."56 These philanthropists viewed charity as both a creative, individual vision and the personal responsibility of great men..$^{57}$ Turn-of-the-century philanthropy, exemplified by the transformative gifts of elite industrialists, was the work of eminent individuals who sought to leave their mark on the nation and expected their legacies to endure intact. In this context, the bargain set forth by Dartmouth-charitable gifts in exchange for immutable legacies-still prevailed.

These rich industrialists, anxious to build institutions and better society while also building personal legacies, helped to finally bring about acceptance of the charitable trust form. As Olivier Zunz has remarked: "[A]mbitious new philanthropists placed themselves in opposition to the centuries-old charitable practice of carefully delimiting purpose and beneficiary.... They conceived of their largesse as open-ended so that it might achieve the greatest impact on society. ${ }^{158}$ The recurrent question was how to effect these philanthropic goals within the existing legal framework. As Andrew Carnegie announced in The Gospel of Wealth: "the problem of our age is the proper administration of wealth. ${ }^{59}$ Charity law varied by state and there was no uniform treatment of the body of law, with many states still refusing to recognize trusts with no ascertainable beneficiaries. ${ }^{60}$ However, with great "accumulations of private

${ }^{56}$ ZUNZ, supra note 53, at 8. Merle Curti suggests:

The American emphasis on individual achievement and on sustained activity to that end have also given a distinct stamp to large-scale giving. Having spent untold effort in getting rich, having tasted the sweets and boredom of extravagant spending, some, driven by a never-ceasing lust to achieve, turned to philanthropy. Carnegie and Rockefeller, each relatively frugal in what he spent on himself, set their hearts on giving with the imagination, organization and efficiency that had marked their activities in steel and oil.

Merle Curti, American Philanthropy and the National Character, 10 AM. Q. 420, 429 (1958). Exemplary institutions founded during this period include Cornell University, Stanford University, Johns Hopkins University, the University of Chicago, the Sage Foundation, the Rockefeller Foundation, and the New York Public Library, to name a few. See ZUNZ, supra note 53, at 9-10.

57 See, e.g., ANDREW CaRNegie, The Gospel of Wealth (1889) (describing the duty of the wealthy as the administration of excess funds to produce the most beneficial results for the community).

58 ZUNZ, supra note 53, at 12.

${ }^{59}$ CARNEGIE, supra note 57. Carnegie condemned the practice of giving through bequests and charitable trusts, stating: "Men who leave vast sums in this way may fairly be thought men who would not have left it at all, had they been able to take it with them. The memories of such cannot be held in grateful remembrance, for there is no grace in their gifts." Id. Carnegie supported high estate taxes at death and urged all those with philanthropic leanings to give during their lives. Id.

${ }^{60}$ See infra text accompanying notes $68-71$. 
wealth, the need for effective mechanisms to enforce and sustain charitable gifts became increasingly manifest." 61 Similarly, a public policy of encouraging charitable giving coalesced as "courts began to recognize the necessity of encouraging contributions to further the welfare of a pioneer society by private means, thereby reducing the expenses of the government." 62

Ultimately, many state legislatures-influenced by the Tilden Trust decision, in many cases-admitted the necessity of the charitable trust form and enacted charitable corporation acts. These major philanthropists helped to render charitable trusts "favorites of the law." ${ }^{3}$ These same philanthropists, inspired by personal visions of the greater good, also reaffirmed the notion that donor intent was a primary value and that great instances of charitable giving were to be rewarded with perpetual application of restrictive terms.

\section{B. Overcoming Opposition to the Cy Pres Doctrine}

The cy pres doctrine, a doctrine of deep but obscure historical roots, ${ }^{64}$ allows courts to modify the terms of an outdated or excessively narrow trust agreement. Cy pres derives from Norman French and means "as near," the full phrase being "cy pres comme possible," or "as near as possible."65 Originally the monarch exercised the cy pres power; however, the doctrine subsequently evolved to provide that "equity will, when a charity is originally or later becomes impossible or impracticable of fulfillment, substitute another charitable object which is believed to approach the original purpose as closely as possible." ${ }^{66}$ The modern statement of the doctrine, which is less exacting,

${ }^{61}$ FisCH, supra note 31, at 117.

${ }^{62} \mathrm{Id}$.

${ }^{63}$ Id. at 118. See also In re Knouse's Will, 121 N.W.2d 151, 153 (Iowa 1963) ("Other general principles of the law as it relates to charitable trusts are that they are favorites of the law."); In re Porter's Estate, 187 P.2d 520, 525 (Kan. 1947); In re Pruner's Estate, 162 A.2d 626, 629 (Pa. 1960) ("Charities are favorites of the law and a gift, even for a specific charitable purpose, should be liberally construed whenever reasonably possible.").

${ }^{64} \mathrm{FISCH}$, supra note 31, at 3 ("The doctrine of cy pres ... was known and used in Rome before Constantine ... . A case applying the cy pres principle appears in the Digest of Justinian."). "So far as can be ascertained, [the term] cy-près first appears in Littleton's Tenures (c. 1481)." L.A. SHeridan \& V.T.H. DelanY, THE Cy-Près DoctRINE 5 (1959). Cy pres originated, in part, as an intent-defeating doctrine. The classic example of this is found in Da Costa v. De Pas, (1754) 27 Eng. Rep. 150 (Ch.). In that case the king used his cy pres power to allot money designated for the purpose of teaching Jewish law and religion to instruct foundlings in the Christian religion. Id. at 151-52 ("[H]is Majesty . . . was graciously pleased ... to give $£ 1000$ part of the said sum of $£ 1200$ towards supporting a preacher, and to instruct the children under their care in the Christian religion.").

${ }^{65}$ George G. Bogert \& George T. Bogert, THE LaW OF Trusts and Trustees $\S 431$ (2013). "The fairly common usage, 'si pray,' seems to be a mixture of French and English pronunciation." Id.

${ }^{66}$ Id. 
provides that the court will modify the trust terms "in a manner consistent with the settlor's charitable purposes." 67

Cy pres doctrine developed in America alongside and in step with the law of charitable trusts. Like the charitable trust, the cy pres doctrine encountered significant judicial resistance in early state courts because of its association with English law and royal prerogative. Nonetheless, over time, cy pres gained legal acceptance and courts began to use it in order to modify trust terms. In this section, I describe the gradual acceptance of cy pres as well as the current status of the doctrine.

\section{Resistance to Prerogative Cy Pres Power}

Because of strong judicial resistance to the charitable trust form as a vehicle for philanthropy, the cy pres doctrine was largely irrelevant and rarely invoked as a tool for modifying trust terms in the years directly following the Revolution until after the Civil War. ${ }^{68}$ In fact, "[o]f the fifteen states which by 1860 had occasion to consider the cy pres doctrine, the courts of some ten states had either condemned or repudiated the doctrine." 69 Of the five states that approved the doctrine, some of the state courts applied the doctrine without naming it, and Kentucky applied it once in 1839 only to repudiate it in later cases. ${ }^{70}$ Before 1860 , only Pennsylvania had enacted a cy pres statute. ${ }^{71}$

For the most part, courts that considered the cy pres doctrine rejected it because of confusion concerning jurisdictional questions and the association of cy pres with royal prerogative. In England, two types of cy pres-prerogative and judicial-had developed over the years. ${ }^{72}$ Many American courts, believing that cy pres derived from the prerogative power of the monarch and not from the equitable jurisdiction of Chancery (a belief perpetuated in part by the Hart case) reacted to the doctrine with antagonism. ${ }^{73}$

67 UNIF. TRust CODE $\S 413$ (2010).

${ }^{68} \mathrm{FiSCH}$, supra note 31 , at 117 ("Until the middle of the nineteenth century, because there were few charitable trusts, the need for the application of the cy pres doctrine was rarely felt.").

69 Id. at $115-16 \mathrm{n} .1$.

${ }^{70} \mathrm{Id}$.

71 Id.

72 See BOGERT \& BOGERT, supra note $65, \S 432$. "The prerogative power is vested in the crown, as parens patriae, and is exercisable by the sign manual of the king, that is, by a direction of the crown under his signature." Id. Judicial cy pres was that exercised by the Court of Chancery. Id. See also Hamish Gray, The History and Development in England of the Cy-Pres Principle in Charities, 33 B.U. L. REV. 30 (1953).

73 See FISCH, supra note 31, at 116 (Deeming the cy pres doctrine contrary to the spirit of our democratic institutions, and in conflict with the doctrine of separation of powers, the early courts reviled and excoriated the English charity doctrine."). In Bascom, the New York court stated that, even if Chancery's cy pres jurisdiction predated the Statute of Charitable Uses, it was "an excrescence upon the common law, inappropriate even to a government in which the crown and the mitre were in mutual alliance and dependence." Bascom $v$. 
In Fontain v. Ravenel, ${ }^{74}$ a leading case at the time, the Court referenced the Hart case as evidence that cy pres was a uniquely prerogative power: "there can be no doubt that the power of the crown to superintend and enforce charities existed in very early times; and ... [t]hat it is a branch of prerogative, and not a part of the ordinary powers of the chancellor, is sufficiently certain." 75 Accordingly, the Court concluded that "[p]owers not judicial, exercised by the chancellor merely as the representative of the sovereign, and by virtue of the king's prerogative as parens patrice, are not possessed by the circuit courts." 76 State courts followed suit. The New York high court, in determining that a charitable trust was void, remarked: "In England, the cy pres power would be exerted ... by a master of the Court of Chancery, or the crown would appoint the charity under the sign manual. In either mode of exercising that power, it rests upon prerogative, and ... does not belong to our judicial system." 77

The support for an opposing view-that judicial and royal prerogative cy pres were in fact two different things-came from Girard and the line of cases that followed. These cases, based on the Girard court's new understanding of Chancery's powers, posited that Chancery possessed ordinary jurisdiction over valid charitable trusts before the enactment of the Statute of Charitable Uses. Consequently, American equity courts could, like their early English counterparts, assume judicial cy pres powers. The Kentucky high court, as a consequence, was led to conclude as early as 1836 that judicial cy pres was available "where there is an available charity to an identified object, and a particular mode is prescribed which is not available. Then a court of equity may substitute, or sanction, some other mode to effectuate the declared intention of the donor; but cannot declare an object for him." 78

By the end of the century, the concept of judicial cy pres had become common. In In re Creighton's Estate, ${ }^{79}$ the Nebraska high court said, "it needs no argument or elaboration to reach the conclusion that, under our system of equity jurisprudence, the [cy pres] powers exercised are purely judicial, derived solely from the organic law, and the statutes, including the common

Albertson, 34 N.Y. 584, 605 (1866).

7458 U.S. (1 How.) 369 (1854).

${ }^{75} \mathrm{Id}$. at 389 (internal quotations omitted).

${ }^{76} \mathrm{Id}$. at 384 . The Court further stated that "[a]n arbitrary rule in regard to property, whether by a king or chancellor, or both, leads to uncertainty and injustice." Id. at 389.

77 Bascom, 34 N.Y. at 594 (quoting Beekman v. Bonsor, 23 N.Y. 298, 311 (1861)). See also Beekman, 23 N. Y. 298; Miller v. Teachout, 24 Ohio St. 525, 529 (1874) ("The English doctrine of $c y$ pres is not the law here-it resting entirely on prerogative, and being foreign to our judicial system and form of government.").

${ }^{78}$ Moore's Heirs v. Moore's Devisees, 34 Ky. (1 Dana) 354, 366 (1836). See also Erskine v. Whitehead, 84 Ind. 357, 364 (1882) ("It is . . well established that there is a cy pres power, which is judicial in its origin and character, recognized and exercised by the English and by the American courts generally.").

7984 N.W. 273 (Neb. 1900). 
law...."80 Courts had reframed judicial understanding of Chancery's historical powers and found arguments to counter those concerning the arbitrary nature of prerogative power. ${ }^{81}$

\section{Modern Judicial Application of Cy Pres}

Between 1900 and 1949, twenty-one jurisdictions applied the cy pres doctrine for the first time. ${ }^{82}$ By 1950 , twenty-nine states had judicially adopted the doctrine ${ }^{83}$ By 2004 , the doctrine was either statutorily or judicially accepted by all states except Alaska and North Dakota. ${ }^{84}$ The doctrine has been adopted in the Restatement of Trusts and the Uniform Trust Code. The Uniform Trust Code's formulation of the cy pres doctrine provides:

If a particular charitable purpose becomes unlawful, impracticable, impossible to achieve, or wasteful: (1) the trust does not fail, in whole or in part; (2) the trust property does not revert to the settlor or the settlor's successors in interest; and (3) the court may apply cy pres to modify or terminate the trust by directing that the trust property be applied or distributed, in whole or in part, in a manner consistent with the settlor's charitable purposes. ${ }^{85}$

\footnotetext{
${ }^{80} I d$. at 275.

${ }^{81}$ See FisCH, supra note 31 , at 120 ("[T]he problem of enforcing and upholding the ever increasing number of charitable trusts, the public policy underlying ... induc[ed] the courts to dispel the mists of confusion that had enshrouded the cy pres doctrine for many years,
} and to adopt an attitude of liberal application.").

${ }^{82} \mathrm{Id}$. at $120 \mathrm{n} .16$.

83 Id. at 92.

${ }^{84}$ See Fremont-Smith, supra note 31 , at 173 . The following states have statutorily authorized cy pres: ALA. CODE $\S 35-4-251$ (1975) (repealed in 2007); ARIZ. REV. STAT. ANN. § 14-10413 (2009); CAL. Prob. CoDe $\S \S 15407,15410$ (West 1990); Del. CodE ANN. tit. 12, § 3541 (2007); GA. CODE ANN. § 53-4-62 (1996); IND. CODE § 30-4-3-27 (1971); LA. Rev. Stat. ANN. §§ 9:2331-9:2337 (1954); MD. CODE ANN., Est. \& TRUSTS $\S 14-302$ (LexisNexis 1974); MASS. GEN. LAWS ch. 12, § 8K, ch. 214, §§ 3(10), 10B (1979); MICH. Comp. Laws § 554.351 (1915); MinN. STat. § 501B.31(2) (1989); Mo. Rev. Stat. $\S \S 166.101$ (1963) (gift for educational purposes), 352.210 (1939) (surplus on dissolution of religious or charitable association); MONT. CODE ANN. $§ 72-33-504$ (1989) (repealed in 2013); N.H. Rev. StaT. ANN. § 498:4-a (1971); N.M. STAT. ANN. § 46A-4-413 (2003); N.Y. EST., POWERS \& TRUSTS LAW § 8-1.1(c) (McKinney 1985); N.C. GEN. STAT. § 36A-53 (1991) (repealed in 2006); OKLA. STAT. tit. 60, $\S 601-602$ (1965); 20 PA. Cons. STAT. $\S 7740.3$ (2006); R.I. GEN. Laws $\& 18-4-1$ (1956); S.D. CODIFIED LAWS \& 55-9-4 (1955); UTAH CODE ANN., $\S 75-7-413$ (LexisNexis 2004); VT. STAT. ANN. tit. 14, § 2328 (1985); W. VA. CODE § 35-2-2 (1931); WIS. STAT. § 701.10(2)(a), (d) (1971); Wyo. STAT. ANN. § 4-10414 (2003). See BOGERT \& BOGERT, supra note $65, \S 433$, n.6 for a survey of the status of cy pres in other jurisdictions.

${ }^{85}$ UNIF. TRUST CODE $\S 413$ (2010). “[I]n a manner consistent with the settlor's charitable purposes" is the standard phraseology that is meant to replace "as near as possible." This change may in and of itself be considered a liberalization. 
Similarly, UPMIFA - adopted by forty-nine states, the District of Columbia, and the U.S. Virgin Islands as of $2015^{86}$-allows for the use of cy pres as a tool for modifying restrictions placed on institutional funds. ${ }^{87}$ UPMIFA clarifies that "the doctrines of cy pres and deviation apply to funds held by nonprofit corporations as well as to funds held by charitable trusts." 88

A cy pres action begins with the trustees or directors. Once the trustees determine that the trust terms have become "unlawful, impracticable, impossible to achieve, or wasteful," $" 89$ they file a cy pres petition seeking to modify the conditions. The trustees are the proper party and the only party with standing to seek such modifications. ${ }^{90}$ According to UPMIFA, the trustees or directors also "shall notify the [Attorney General] of the application, and the [Attorney General] must be given an opportunity to be heard"91 at the time of filing the petition. Once the petition has been filed, a court applies a three-part test to evaluate whether cy pres is appropriate. In the absence of contravening language in the trust itself, a court must determine that: (1) a valid charitable trust exists; (2) the trust's purpose is illegal, impractical, or impossible, and (3) the donor possessed a general charitable intent. ${ }^{92}$ If these conditions are met, the court will modify the terms of the trust such that they are as near as possible to those of the original gift. ${ }^{93}$

${ }^{86}$ Legislative Fact Sheet-Prudent Management of Institutional Funds Act, UNIFORM
LAW http://uniformlaws.org/LegislativeFactSheet.aspx?title=Prudent $\% 20$ Management $\% 20$ of $\% 20$ Institutional\%20Funds\%20Act [http://perma.cc/ME4P-4T66] (listing jurisdictions that have adopted the UPMIFA).

87 UNIF. PRUDENT MGMT. OF INSTITUTIONAL FundS ACT $\S 6$ 6(c) (2006) ("If a particular charitable purpose or a restriction contained in a gift instrument on the use of an institutional fund becomes unlawful, impracticable, impossible to achieve, or wasteful, the court, upon application of an institution, may modify the purpose of the fund or the restriction on the use of the fund in a manner consistent with the charitable purposes expressed in the gift instrument.").

${ }^{88}$ Unif. Prudent Mgmt. OF InStitutional Funds ACT at 4 (2006). The comment to Uniform Trust Code $\S 413$ states that "[t]he doctrine of cy pres is applied not only to trusts, but also to other types of charitable dispositions, including those to charitable corporations." UNIF. TRUST CODE $\S 413 \mathrm{cmt}$. (2010).

${ }^{89}$ UNIF. TRUST CODE $\S 413(2010)$.

${ }^{90}$ In the case of restricted gifts not in the form of a trust, the beneficiary institution may file a cy pres petition.

${ }^{11}$ UNIF. PRUDENT MGMT. OF INSTITUTIONAL FUNDS ACT $\S 6(\mathrm{c})$ (2006).

92 See Unif. Trust Code $\S 413$; Restatement (Third) OF Trusts $\S 67$ (2003). This formulation has been widely adopted by courts as well. See, e.g., Kolb v. City of Storm Lake, 736 N.W.2d 546, 555 (Iowa 2007).

${ }_{93}$ In re Elizabeth J.K.L. Lucas Charitable Gift, 261 P.3d 800, 809 (Haw. Ct. App. 2011) ("Finally, in applying cy pres, courts must generally seek a purpose that conforms to the donor's objective 'as nearly as possible."' (quoting Am. Jur.2d § 157)). A comment to section 67 of the Restatement (Third) of Trusts states that the modified purpose "need not be the nearest possible but one reasonably similar or close to the settlor's designated purpose." 
The first of these requirements-the valid charitable trust-has "crumbled" somewhat as the doctrine has been applied more regularly and courts have "impl[ied] a valid charitable trust where only a simple gift had been made to charity."94 Some scholars suggest that courts have also progressively relaxed the second requirement-that a trust's purpose be illegal, impractical, or impossible. ${ }^{95}$ Historically, courts found gift terms to be impossible or impracticable when the purpose was no longer available or relevant. For example, once the days of frontier building were clearly over, a court modified the conditions placed on a gift meant to "furnish relief" to immigrants and travelers coming to Saint Louis on their way "to settle the West." 96 Courts have also found certain idiosyncratic conditions-such as a bequest to "maintain a hospital for ailing Siamese cats"97 — to be impracticable and have judicially modified the gift conditions in order for funds to be spent.

More recently, courts have almost universally removed racially restrictive trust terms as violative of equal protection law and modified the trusts accordingly through the application of cy pres. ${ }^{98}$ In cases of trusts with religious or gender-based restrictions, courts generally assume that the donor would have preferred the charitable trust to continue even without the restrictive terms. ${ }^{99}$ For example, in Howard Savings Institution of Newark, N. J. v. Peep, ${ }^{100}$ the New Jersey high court used cy pres to strike conditions from a bequest intended to provide scholarship monies to Amherst College. ${ }^{101}$ The testator bequeathed money to Amherst College "to be held in trust to be used as a scholarship loan fund for deserving American born, Protestant, Gentile boys of good moral repute, not given to gambling, smoking, drinking or similar acts." 102 Amherst refused to accept the gift with those conditions

\footnotetext{
RESTATEMENT (THIRD) OF TRUSTs $\S 67 \mathrm{cmt}$. d (2003).

94 Chester, supra note 12, at 416.

${ }^{95}$ Id. (pointing out the "courts' increased willingness to discover 'impossibility' when confronted with what they considered a much better use of the bequest"). See also FisCH, supra note 31 , at 139.

96 Simes, supra note 15 , at 127.

97 Id. at 118.

98 See David Luria, Prying Loose the Dead Hand of the Past: How Courts Apply Cy Pres to Race, Gender, and Religiously Restricted Trusts, 21 U.S.F. L. REV. 41 (1986). David Luria found that out of forty cases challenging restrictive and discriminatory trusts terms, the courts attempted to reform the terms through the application of cy pres in twenty-nine of the cases. Id. at 42-43. See, e.g., Evans v. Newton, 382 U.S. 296, 301-02 (1966); Pennsylvania v. Brown, 392 F.2d 120, 123 (3d Cir. 1968).

99 But see Evans v. Newton, 382 U.S. 296 (1966) (concluding that the trust could not be modified and that the trust therefore failed).

100170 A.2d 39 (N.J. 1961).

${ }^{101} \mathrm{Id}$. at 48 ("[W]e hold that the testator's intent can be effectuated as nearly as possible by striking the Protestant-Gentile restriction and turning the funds over to Amherst to be administered in accordance with the remaining terms and conditions of the trust.").

102 Id. at 41 .
} 
attached to the scholarship, and the court concluded that "[w]ithout Amherst's cooperation the administration of this trust would be so impracticable as to defeat the general purpose of the testator." 103 In a similar case in New Hampshire, in which scholarship money was to be given to Protestant boys, the state high court remarked: "[O]ur cy pres statute ... directs our courts to reform the illegal purpose, not to preserve it as far as possible by modifying those provisions requiring public administration of the trust."104

Some commentators have remarked that "policy considerations and concern for furthering the public welfare [have become] of increasing importance in delimiting and defining the degree and type of impracticality necessary to call the cy pres doctrine into operation." 105 Other critics have asserted that, even in instances of liberal interpretation, courts set too high a standard for determining whether a trust's terms are impossible or impractical. ${ }^{106}$ Furthermore, critics claim that courts apply the standard inconsistently. As the Iowa high court observed in Kolb v. City of Storm Lake: 107 "[A] review of the case law on impossibility and impracticability has led many to believe 'no precise definition of the standard exists,' and whether something has become impossible or impracticable is up to the 'particular facts of each case.' We agree." 108

The third prong of the test is the requirement of a general charitable intent. The Uniform Trust Code has addressed this question and, as discussed in the next section, shifted the presumption in favor of general charitable intent. Some scholars have gone further and proposed the total elimination of this requirement, ${ }^{109}$ suggesting that all charitable gifts inherently possess general

103 Id. at 46 . The testator was held to have a general charitable intent to benefit Amherst, his alma mater. $I d$. at 48 .

104 In re Certain Scholarship Funds, 575 A.2d 1325, 1329 (N.H. 1990).

$105 \mathrm{FiSCH}$, supra note 31, at 143.

106 FREMONT-SMITH, supra note 31, at 178 ("Major criticism has also been directed at the second requirement-that it must be impossible or impracticable to carry out the donor's purposes. Proponents of change have advocated that it should be sufficient to show that it inexpedient or not in the public interest to carry out the stated purposes of the trust.").

107736 N.W.2d 546 (lowa 2007).

${ }^{108} \mathrm{Id}$. at 556 (citation omitted). The court concluded that cy pres was applicable when a charitable trust created to build and maintain a fountain and garden at a certain location could no longer fulfill its terms after the city razed the garden in order to make room for a major economic development project. "Such a massive project should be planned in a way that maximizes its potential, and when the location of the garden and fountain jeopardize that potential it becomes impractical not to relocate them." Id. at 557.

109 See, e.g., Ronald Chester, Cy Pres or Gift Over: The Search for Coherence in Judicial Reform of Failed Charitable Trusts, 23 SUFFOLK U. L. REV. 41, 44 (1989) ("A court need not attempt to find a general charitable intent in order to apply cy pres."); Lopez, supra note 13, (advocating for a specific charitable intent presumption, rather than the general charitable intent one). See also Jonathan R. Macey, The Private Creation of Private Trusts, 37 EMORY L.J. 295, 306 (1988) (advocating for an "alternative rule which stipulates that the 
charitable intent. Courts that do not presume general charitable intent consider "both the express language of the instrument, as well as extrinsic evidence." 10 General judicial procedure, in these cases, requires the application of the following test: "If the testator had known that it would be impossible to follow the express terms of the charitable bequest, would he or she prefer to bequeath the funds to a similar charitable purpose or have his or her largess be treated like all other ineffective bequests."111 The focus, critics contend, remains on donor intent and the undertaking is an exercise in reconstructing donor intent from all relevant sources, with emphasis on the agreement itself.

\section{MAPPING CY PRES REFORM}

Because of the particular way in which charitable giving regulation has developed, donor intent-- bounded by the charitable purposes doctrine-has traditionally been the principle governing judicial cy pres analysis. This focus on donor intent has been the subject of academic critique. One commentator has remarked that, "[n]otwithstanding the potential for a meaningful public benefit, donor intent-not public interest-remains paramount in the administration and modification of charitable trusts." 12 These critics have lamented the lack of meaningful reform, ${ }^{113}$ or, relatedly, stated that reform has made the doctrine too confused and confusing. ${ }^{114}$

While scholars have consistently highlighted the shortcomings in cy pres doctrine and the cautious nature of reform, reform has nevertheless come. In the past decade, reform efforts have produced significant changes in the way

settlor's assets always revert back to his heirs whenever any significant aspect of the settlor's intentions are thwarted, unless the settlor provides for a contrary result, would serve the interests of efficiency at least as well. Such a rule would provide a better guide to courts on the value to the settlor of his second choice asset allocation.").

110 See Nat'l Soc. of Daughters of Am. Revolution v. Goodman, 736 A.2d 1205, 1210 (Md. Ct. Spec. App. 1999).

${ }_{111}$ Id. (citation omitted).

112 Ilana H. Eisenstein, Keeping Charity in Charitable Trust Law: The Barnes Foundation and the Case for Consideration of Public Interest in Administration of Charitable Trusts, 151 U. PA. L. REv. 1747, 1754 (2003). See also Vanessa Laird, Phantom Selves: The Search for a General Charitable Intent in the Application of the Cy Pres Doctrine, 40 STAN. L. REV. 973, 974 (1988) (stating that cy pres analysis is constructed to suggest that "whatever the court does, it does with the consent of the phantom testator").

113 Atkinson, supra note 13, at 97 (stating that despite this barrage of reformist activity and scholarship, "[t]hese calls, for all their merit, have gone virtually unheeded"). See also Alex M. Johnson, Jr. \& Ross D. Taylor, Revolutionizing Judicial Interpretation of Charitable Trusts: Applying Relational Contracts and Dynamic Interpretation to Cy Pres and America's Cup Litigation, 74 IOWA L. REv. 545, 567 (1989) ("Although commentators often have attacked the conservative approach to cy pres-pointing out its suboptimal use of trust assets--and have called for its expansion, courts have resisted relaxing the doctrine.").

114 John K. Eason, Motive, Duty, and the Management of Restricted Charitable Gifts, 45 WAKE FOREST L. REV. 123, 125-26 (2010). 
the Uniform Trust Code, the Restatement of Trusts, and some state courts approach the cy pres doctrine. Three reforms in particular have brought significant changes for cy pres doctrine. First is the shift in presumption concerning general charitable intent; second is the addition of "wasteful" as a criterion for cy pres application; and third is the use of the doctrine of deviation. In this Part, I describe and analyze recent high-profile cy pres cases that have provoked controversy, and have both exemplified the need for and furthered reform efforts. What emerges from this collection of litigation is a map of successful reform efforts as well as a blueprint for the continued refinement of cy pres.

\section{A. Fisk and the Presumption of General Charitable Intent}

The third prong of the cy pres test-the requirement of a general charitable intent-has provoked great debate among scholars and legal commentators. For many years, critics were disappointed that so little "progress ha[d] been made in modifying the rule requiring a general charitable intent be the settlor." 115 Moreover, there were no more than "a few cases in the latter half of the twentieth century in which the courts did broaden the application of the doctrine by assuming general charitable intent."116 The problem with finding general charitable intent was clearly stated by Scott, who observed in his treatise:

[T]he trust does not fail if the testator has a more general intention to devote the property to charitable purposes.... This principle is easy to state but is not always easy to apply. ... Indeed it is ordinarily true that the testator does not contemplate the possible failure of his particular purpose, and all that the court can do is to make a guess not as to what he intended but as to what he would have intended if he had thought about the matter. ${ }^{117}$

Courts in cy pres cases were faced with a decision between allowing cy pres modifications or reversion to the donor's heirs. In order to make this choice, courts engaged in speculative inquiries about what a donor might have done had she still been alive or foreseen the changed circumstances. Restating why courts struggle to effectuate this principle, one scholar has suggested that traditional cy pres analysis is constructed such that "whatever the court does, it does with the consent of the phantom testator."118

Reform measures, however, have shifted judicial norms. In 2003, the Uniform Trust Code, following similar modifications to the Restatement

115 Chester, supra note 12 , at 417 . Chester attributes this lack of progress to "the persistence of the requirement of general charitable intent, a remnant of the stress on individual property rights so prevalent in Anglo-American common law." Id. at 424.

116 FREMONT-SMITH, supra note 31, at 176.

1174 Austin WaKeMAN SCOTT, The LAw OF TRUSTS $\$ 399.2$ (3d ed. 1967).

118 Laird, supra note 112, at 974. 
(Third) of Trusts in 2001, modified the cy pres doctrine to include a presumption of general charitable intent. ${ }^{119}$ In the comment to this section, the drafters remarked, "traditional doctrine did not supply that presumption, leaving it to the courts to determine whether the settlor had a general charitable intent." 20 The drafters added that "[c]ourts are usually able to find a general charitable purpose to which to apply the property, no matter how vaguely such purpose may have been expressed by the settlor."121 As of 2015, the Uniform Trust Code had been adopted by thirty-one states. ${ }^{122}$

Even in states that have not adopted the Uniform Trust Code, courts are relaxing the level of proof required to show general charitable intent. This relaxation is not happening, however, without deliberation and contestation in the state courts. A good example of the difficulties stemming from the lack of a presumption of general charitable intent--and the extended litigation that it can produce-is the Fisk case. ${ }^{123}$ Fisk University, a historically black university founded in 1866 , was the recipient of 101 paintings that were donated by Georgia O'Keeffe in the late 1940s and early 1950s. ${ }^{124}$ Four of the paintings were the property of Georgia O'Keeffe, and the rest O'Keeffe gave to the school from the Alfred Steiglitz collection, in her capacity as executrix of his estate. ${ }^{125}$ "All 101 pieces were charitable, conditional gifts that were subject to several restrictions, two of which are at issue here; the pieces could not be sold and the various pieces of art were to be displayed at Fisk University as one collection."'126

The controversy over the paintings began in 2005 when the University sought a Declaratory Judgment for permission to sell two valuable paintings from the Alfred Stieglitz Collection, Radiator Building-Night, New York by Georgia O'Keeffe and Painting No. 3 by Marsden Hartley. ${ }^{127}$ As stated in the petition, the "purpose of the proposed sale was to generate funds for the University's 'business plan' to restore its endowment, improve its mathematics, biology, and business administration departments, and build a new science building." 28 Before the court had rendered any judgment, the

119 UNIF. TRUST CODE $\S 413$ (a) (2010); RESTATEMENT (THIRD) OF TRUSTS $\S 67$ (2003).

${ }^{120}$ UNIF. TRUST CODE $\S 413(\mathrm{a}) \mathrm{cmt}$. at 78 (2010).

$121 \mathrm{Id}$.

122 See supra note 14 and accompanying text.

${ }^{123}$ Georgia O'Keeffe Found. (Museum) v. Fisk Univ., 312 S.W.3d 1, 4 (Tenn. Ct. App. 2009). For a discussion of the problems of general versus specific intent in the Fisk case, see Leslie, supra note 13 , at 10-15.

${ }^{124}$ O'Keeffe, 312 S.W.3d at 4.

$125 \mathrm{Id}$.

$126 I d$.

127 Id

$128 \mathrm{Id}$. For further discussion on deaccessioning and the limits imposed by industry rules on institutions, see Allison Anna Tait, Publicity Rules for Public Trusts, 33 CARdozo ARTs \& ENT. LAW J. (forthcoming 2015). 
University changed its request to sell the paintings into a request for approval of a settlement agreement with the Crystal Bridges Museum of American Art, in Bentonville, Arkansas. The proposed agreement provided that "the University would sell a 50\% undivided interest in the entire Collection for $\$ 30$ million. ... [and] the University and Crystal Bridges would each have the right to display the Collection at their respective facilities six months of each year." 129

In its amended complaint, the University sought relief from the conditions placed on the gifted paintings, pursuant to the cy pres doctrine. ${ }^{130}$ The University contended that its "bleak financial circumstance" rendered compliance with the gift impractical, as did "other material changes in circumstances that have occurred in the more than fifty years since the conditional gifts were made." 131 Applying New York law because the paintings had been located in New York before being bequeathed to Fisk, the Tennessee Chancery Court denied the University's amended request, and concluded that O'Keeffe had specific and not general charitable intent in giving the artwork to Fisk. ${ }^{132}$

The Chancery Court began its analysis by discussing the importance of donor intent ${ }^{133}$ and the exact sources the court was using in order to determine donor intent. ${ }^{134}$ Relying on probate documents, correspondence, and personal statements, the court acknowledged that "indicative of a general charitable intent is that the Stieglitz Will and the O'Keeffe gifts consisted of donations not just to Fisk but other charities." 135 The Court also noted that there was no gift over provision in the donation. ${ }^{136}$ However, the court also observed that "indicative of a specific intent are the intentions of a social statement and control and the proof supporting them ...."137

Determining whether O'Keeffe's intent was general or specific, the court remarked that making any such determination was "elusive" 138 and that "it is difficult to extract a concrete definition or principle to guide the Court in discerning in this case whether the intent is general or specific." 139 The court also remarked, "the question whether a settlor had general charitable intent

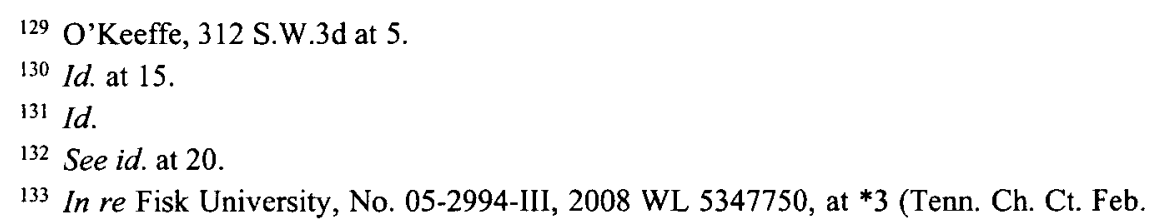
8,2008 ) ("It is, then, critical in the first instance for a court to isolate and identify exactly what the donor's intent was in making a gift.").

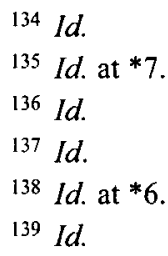


beyond the specific purpose mentioned is 'just another way of asking what the settlor would have done under the circumstances." 140 Confronted with the question, however, the court decided that the facts of the record supported a finding of specific charitable intent. ${ }^{141}$

The Court of Appeals disagreed. ${ }^{142}$ The appellate court stated that a donor's general charitable intent could be demonstrated by "other charitable gifts and the provisions of the gift," 143 by "similar charitable gifts to several different charities,"144 and "the absence of a divesting clause."145 Gift provisions stated that the purpose of the gift was to promote the study of art in the South, ${ }^{146}$ and there were no gift over provisions. ${ }^{147}$ In addition, O'Keeffe had made other similar charitable gifts to other charities. ${ }^{148}$ The court also noted that, in favor of finding a general charitable intent, there was also the "legal principle that the courts favor finding a general charitable intent." 149 Consequently, the court stated: "[T] he fact that Ms. O'Keeffe had a specific purpose and imposed specific conditions does not alter the fact that the motivation for the gifts to the University was to promote the study of art in Nashville and the South."150 The appellate court therefore reversed the trial court's finding and remanded the case to determine whether or not the University's financial straits rendered compliance with the gift terms impractical or impossible. ${ }^{151}$

On remand, the trial court concluded that financial necessity did indeed render compliance impossible, based on the uncontradicted testimony of Fisk's President, Hazel O'Leary. ${ }^{152}$ Subsequently, the court evaluated three proposals for revision to the terms of the gift-two put forth by the Attorney General and the one put forth by the University in the amended complaint. ${ }^{153}$ The trial court accepted Fisk's proposal because "(1) the superior resources of the Crystal Bridges Museum ... provide this important Collection excellent support and

140 Id. at *7 (citation omitted).

141 Id. ("TT]he Court concludes that the facts of record demonstrate that the intent was specific that Fisk not have the power to dispose of the Collection.").

142 Georgia O'Keeffe Found. (Museum) v. Fisk Univ., 312 S.W.3d 1, 15 (Tenn. Ct. App. 2009).

143 Id. at 17.

$144 I d$.

$145 \mathrm{Id}$.

$146 \mathrm{Id}$.

147 Id. at 18.

$148 \mathrm{Id}$.

149 Id, at 19.

$150 \mathrm{Id}$. at 18 .

$151 I d$ at 20.

152 In re Fisk Univ., 392 S.W.3d 582, 588 (Tenn. Ct. App. 2011). O'Leary discussed Fisk's budget cuts and financial statements while also demonstrating that that the annual cost to maintain and display the Collection was $\$ 131,000$. Id.

153 Id. at 591 . 
access to the public, and (2) Fisk and Crystal Bridges have modified their agreements to assure that the Collection retains a presence in Nashville."154

When the litigation ended, a writer at the New York Times announced, "[ $t$ ]he long battle over the fate of Fisk University's art collection is finally over."155 One scholar asked: "Why did resolution of this conflict require six years of litigation and the expenditure of enormous amounts of charitable and public dollars?"156 Her answer to the question clearly implicated the cy pres doctrine, stating "[t]he blame lies with the law itself: the centuries-old doctrine of cy pres ... practically guarantee[s] that years of litigation will ensue when a charity finds itself unable to comply with a gift restriction." 157 Confusion resulted from general doubt on the part of the trial court about how to apply the cy pres doctrine to the circumstances at hand, and, more particularly, the application of the general charitable intent principle. Some of the confusion surrounding the principle can be and has been - to the extent that states adopt the Uniform Trust Code-answered by a shift to the presumption of general charitable intent. ${ }^{158}$ In states that have yet to adopt the Uniform Trust Code, the problem can be solved by the willingness of courts, like the Tennessee appellate court, to construe intent broadly. Consequently, the path to reform and the outline of a clearer standard exist within the Fisk litigation and the appellate court's decision.

\section{B. The Buck Trust and Wasteful Economic Conditions}

Fiercely debated questions concerning cy pres have also emerged in connection with the Buck Trust, a charitable trust that had significant surplus income and ran the risk of wasteful management. In the Buck case, doctrinal reform was the direct result of the prolonged and controversial litigation. ${ }^{159}$ Beryl Buck established the Beryl Buck Foundation Trust by bequest in 1975. ${ }^{160}$ Buck's will directed that the trust "shall always be held and used for exclusively non-profit charitable, religious or educational purposes in providing care for the needy in Marin County, California, and for other non-

\section{${ }^{154} \mathrm{Id}$.}

${ }^{155}$ Randy Kennedy, Legal Battle Over Fisk University Art Collection Ends, N. Y. TIMES, August 3, 2012, at C2.

${ }^{156}$ Leslie, supra note 13, at 3.

${ }^{157} \mathrm{Id}$. at 3-4 ("In the Fisk case, the law's fuzziness allowed the [O'Keeffe] Museum-an unrelated third party-to make a grab for the Collection under the guise of effectuating donor's intent. The fact-specific cy pres standard also enabled the Tennessee Attorney General to make it extraordinarily difficult for Fisk to craft a solution involving entities located outside the state of Tennessee.").

${ }^{158}$ Leslie, supra note 13, at 5 ("[A]pplication of certain UTC provisions to the Fisk case would have reduced the length of the litigation and the corresponding waste of charitable assets, to some degree.").

${ }^{159}$ Estate of Buck, 35 Cal. Rptr. 2d 442 (Cal. Ct. App. 1994).

${ }^{160} \mathrm{Id}$. at 442. 
profit charitable, religious or educational purposes in that county."161 At the time of Buck's death, the assets-in the form of Belridge Oil stock-were worth approximately ten million dollars. ${ }^{162}$ Four years later, however, when Shell Oil bought Belridge, oil prices had soared and the trust assets became worth almost 300 million dollars. ${ }^{163}$

Faced with this unexpected and dramatic increase in trust assets, the distribution committee deliberated about how to disburse funds in light of trust terms requiring that the spendable income be used in Marin County, a county with "one of the highest per capita incomes in the country and relatively few charitable needs." 164 Ultimately, the committee, in 1984, "resolved that it was "impracticable and inexpedient to continue to expend all of the income from the Buck Trust solely within Marin County' and authorized the filing of a petition to modify the geographic restriction of Beryl Buck's Trust."'65 The Foundation, in its cy pres petition, requested authorization to "spend an unspecified portion of Buck Trust income outside of Marin County in the four other Bay Area counties preferentially served by the Foundation."166

Once the Foundation filed its petition, a frenzied debate began. John Simon, capturing the over-the-top tenor of the response, recounted that "[t]he petition was characterized as a threat to the sanctity of wills and the health of philanthropy, and as an offense against capitalism, the American way of life, and God."167 A number of motions to intervene were filed, including one by the Marin County Bar Association and another by a self-described collection of "46 Objector Beneficiaries."168 The University of California, Solano County, Mendocino County, and Sonoma County all sought to intervene solely on the question of whether the court should apply cy pres. ${ }^{169}$

In the briefs prepared for trial, the Foundation argued that modification of the gift conditions was appropriate "on the basis of unanticipated changed circumstances, or 'surprise,' and 'inefficiency." 170 The opposing side argued that there were no legal grounds on which to grant cy pres, that there was no "surprise," that Buck's intention was to limit expenditures to Marin County

161 Id. at 443.

162 Ronald Hayes Malone, Mary K. McEachron \& Jay M. Cutler, The Buck Trust TrialA Litigator's Perspective, 21 U.S.F. L. REV. 585, 590 (1987) ("Mrs. Buck's trust was worth ten million dollars at the time of her death but $\$ 260$ million by the close of probate and over $\$ 400$ million at the time of trial.").

$163 \mathrm{ld}$.

164 Malone et al., supra note 162, at 590-91.

$165 \mathrm{Id}$. at 591 .

$166 \mathrm{Id}$.

167 John G. Simon, American Philanthropy and the Buck Trust, 21 U.S.F. L. REV. 641, 641 (1987).

168 Malone et al., supra note 162 , at 594.

$169 \mathrm{Id}$. at $594-95$.

$170 \mathrm{ld}$. at 609 . 
regardless of the value of the trust, and that "any perceived 'inefficiency' or 'ineffectiveness' was attributable to the Foundation's conflicts of interest and improper administration of the Buck Trust, not the Trust's terms, its value, or the nature of Marin County."171 On August 15, 1986, the court entered a judgment denying the cy pres petition. ${ }^{172}$ The court concluded that the Foundation had not proved that it was impossible, illegal, or impracticable, to spend the trust income as directed in the trust terms. ${ }^{173}$ The court also concluded that "[n]either inefficiency nor ineffective philanthropy constitutes impracticability, nor does either concept constitute an appropriate standard for the application of cy pres." 174 The court did, however, agree to hold a hearing in July 1987 in order to select one or more of the "major projects" to be funded, and in August of that year the court directed trust funds be distributed to three "major projects": The Buck Center on Aging, Institute on Alcohol and Other Drug Problems, and Marin Educational Institute. ${ }^{175}$ In addition, the court appointed a special master to oversee the progress of these projects and ordered a "review [of] the progress and operations of each major project annually."176

Thus ended a prolonged process that included a six-month trial that produced nearly 15,000 pages of trial transcript and over 2000 trial exhibits. ${ }^{177}$ Because of the publicity surrounding the case as well as the investment of resources in litigating the case, some called it the "Superbowl of Probate."178 Severe dissatisfaction with the length and expense of the litigation, as well as the outcome, also provoked reformers to advocate for the inclusion of the concept of wastefulness as a criterion for the application of cy pres. Invoking the example of the Buck Trust, reformer advocates argued that "the legal right to dictate through a trust how wealth is to be used after death may lead to economic inefficiency because conditions inevitably will change in ways unforeseen to the settlor."179

The result of this activity was modification to the Uniform Trust Code in 2000 and to the Restatement (Third) of Trusts in 2003. The Restatement states that cy pres may be appropriate when it "becomes wasteful to apply all of the property to the designated purpose."180 The Restatement describes "wasteful" as meaning that the funds far exceed what is necessary, rendering it imprudent

\footnotetext{
171 Id.

${ }_{172} I d$. at 636 (citing In re Estate of Buck, No. 23259, slip op. at 10-11 (Cal. Super. Ct., Marin County, Aug. 15, 1986)).

${ }_{173}$ Id.

174 Id.

175 Id. at 639 n. 284 .

176 Simon, supra note 167 , at 661 .

177 Malone et al., supra note 162, at 610.

178 See id. at 637.

179 Macey, supra note 109, at 297.

180 RESTATEMENT (THIRD) OF TRUSTS $\S 67$ (2003).
} 
not to expand the purposes for which the funds can be applied. ${ }^{181}$ The revised Uniform Trust Code provisions state, "the court may modify an administrative term if continuation of the trust on its existing terms would be impracticable, wasteful, or impair the trust's administration." The Uniform Trust Code revision therefore "expands the ability of the court to apply cy pres." 182 The Uniform Trust Code also, for efficiency reasons, sets forth expedited procedures for reforming small charitable trusts. ${ }^{183} \mathrm{~A}$ trustee may modify or terminate a trust with assets less than $\$ 50,000$ "if the trustee concludes that the value of the trust property is insufficient to justify the cost of administration." ${ }^{\prime 84}$ Fourteen states have enacted statutes providing for similar procedures. ${ }^{185}$

Although these reforms were unavailable to help in the resolution of the Buck Trust case, the reforms may help with other trusts that are generating more income than they can spend. For example, a cy pres challenge has yet to come for the Kamehameha Schools Bishop Estate Trust ("KSBET"). ${ }^{186}$ Alex Johnson has remarked that the "KSBET presents a classic example of a trust in need of modification via the cy pres doctrine to conform to conditions that have changed since it was established by the will of Princess Bernice Pauahi Bishop over 114 years ago." 187 Aside from significant concerns about trustee abuse of power, ${ }^{188}$ a major concern is the efficient utilization of the trust's

181 See id. $\$ 67 \mathrm{cmt} . \mathrm{c}(1)$ ("The term 'wasteful' is used here neither in the sense of common-law waste nor to suggest that a lesser standard of merely 'better use' will suffice."). The Uniform Trust Code was amended in 2001. FREMONT-SMITH, supra note 31, at $177 \mathrm{n} .283$. Arizona, Nebraska, New Mexico and Wyoming have adopted the Uniform Trust Code. $1 d$. at $177 \mathrm{n} .287$. Delaware also includes the language about wasteful purpose in its cy pres statute. $I d$. at 178 . These changes may have come in response to criticism in the wake of legal disputes involving the Buck Trust and the Hershey Trust.

182 David M. English, The Uniform Trust Code (2000) and its Application to Ohio, 30 CAP. U. L. REV. 1, 18 (2002).

${ }^{183}$ FREMONT-SMITH, supra note 31, at 179.

184 See UNIF. TRUST CoDE § 414(a).

${ }^{185}$ FREMONT-SMITH, supra note 31, at 179-80.

186 The Trust has faced other legal challenges, including equal protection challenges to the discriminatory admission policies. See Doe v. Kamehameha Sch./Bernice Pauahi Bishop Estate, 470 F.3d 827, 827 (9th Cir. 2006).

187 Alex M. Johnson, Jr., Limiting Dead Hand Control of Charitable Trusts: Expanding the Use of the Cy Pres Doctrine, 21 U. HAw. L. REv. 353, 353 (1999).

188 In 1999, the trust was "embroiled in a public tangle of boardroom intrigue, questionable investments, IRS audits and allegations of criminal acts." Hawaii Trustees Plagued by Scandal, L.A. TIMES (Mar. 29, 1999), http://articles.latimes.com/1999/mar/29/news/mn-22203 [http://perma.cc/6LPF-YK99]. All five trustees were, at that time, removed from office "after the Internal Revenue Service threatened to strip the estate of its status as a tax-free charitable organization." Samuel P. King \& Randall W. Roth, Erosion of Trust. Hawaii's Bishop Estate: A Cautionary Tale of Mismanagement at a Charitable Organization, 93 A.B.A. J. 48, 49 (2007). The Bishop 
income. Johnson has speculated that, "[i]f all the money ... was spent to support the Kamehameha Schools ... trustees would have to come up with creative ways to spend hundreds of millions of dollars annually to benefit a high school when such expenditures may be unnecessary, wasteful, and downright stupid."189

Similar questions about the amount spent per student have been asked about the Hershey Trust Company and Milton Hershey School. This trust "has yielded an embarrassment of riches, which now includes almost $\$ 800$ million in accumulated income, far more than the school needs for its 1,163 students, who receive free room, board, clothes, books, bikes and backpacks." 190 However, in 2002 when the school announced a plan to diversify the trust's investment portfolio by selling its controlling interest in the Hershey Company, public outrage was immediate. ${ }^{191}$ Although the Company's stock jumped almost fifteen dollars based on news of the sale, the Attorney General-who was running for Governor-obtained a preliminary injunction, and the trustees abandoned the sale, causing the stock price to drop back down. ${ }^{192}$ Robert Sitkoff and Jonathan Klick have argued that "the Attorney General's intervention preserved charitable trust agency costs on the order of roughly $\$ 850$ million and foreclosed salutary portfolio diversification."193 They further estimate that the blocked sale "destroyed roughly $\$ 2.7$ billion in shareholder wealth, reducing aggregate social welfare by preserving a suboptimal ownership structure of the Hershey Company." 194

The Hershey Trust, like the Bishop Estate, may present an opportunity for cy pres modification, depending on whether petitioners can prove that the income of each trust is excessive to its purpose. If income is excessive, as it was in the Buck case, petitioners may be able to leverage the concept of "wasteful" to facilitate amendment of trust terms. Consequently, introducing

\footnotetext{
Estate "has been referred to as "the Enron of charities." Id. at 50 .

189 Johnson, supra note 187 at 362.

190 Tamar Lewin, Alumni Fight for 'Soul' of Richest Orphanage, N.Y. TIMES (Nov. 30, 2000), http://www.nytimes.com/2000/11/30/us/alumni-fight-for-soul-of-richestorphanage.html [http://perma.cc/KC4S-FCN9].

191 See Jennifer L. Komoroski, The Hershey Trust's Quest to Diversify: Redefining the State Attorney General's Role When Charitable Trusts Wish to Diversify, 45 WM. \& MARY L. REv. 1769, 1787 (2004) ("[T]he Pennsylvania Attorney General, in his parens patriae role, sought to block the sale by petitioning a court to order the trustees of the Hershey Trust to show cause as to why the sale of the trust's controlling interest in Hershey Foods should not require court approval.").

192 Robert H. Sitkoff \& Jonathan Klick, Agency Costs, Charitable Trusts, and Corporate Control: Evidence from Hershey's Kiss-Off, 108 CoLuM. L. REv. 749, 749 (2009). Sitkoff and Klick remark that many of the problems in this case may have resulted from the Attorney General's desire to use the Hershey Trust situation to further his personal agenda as a political candidate. $I d$. at 781-82.

193 Id. at 749.

${ }^{194}$ Id.
} 
the concept of economic waste into cy pres analysis has been an important reform and provided trustees and nonprofit institutions with a new tool for obtaining increased spending flexibility.

\section{The Barnes Trust and the Doctrine of Deviation}

Another highly publicized and hotly contested case, the Barnes Trust case, has highlighted the utility of a related change of circumstances doctrine, the doctrine of deviation and reform to that doctrine. ${ }^{195}$ The doctrine of deviation, applicable to both charitable and private trusts, allows a court to "modify an administrative or distributive provision of a trust, or direct or permit the trustee to deviate from an administrative or distributive provision, if because of circumstances not anticipated by the settlor the modification or deviation will further the purposes of the trust." 196 The provision allowing for deviation from distributive provisions was a major change brought about by section 167 of the Restatement (Second) of Trusts, and was not found in prior law. This change concerning distributive provisions influenced language in the Uniform Trust Code as well. The current version of the Uniform Trust Code states, "[ $[\mathrm{t}] \mathrm{he}$ court may modify the administrative or dispositive terms of a trust or terminate the trust if, because of circumstances not anticipated by the settlor, modification or termination will further the purposes of the trust." 197 The main difference between cy pres and deviation is that the latter is considered to be a more liberal tool in reforming charitable trust terms. 198 "Courts appear to apply the deviation doctrine in situations short of impossibility, particularly when 'effective philanthropy' or the public interest is paramount." 199 Deviation is therefore another useful tool for institutions looking to increase their flexibility and ability to modify gift conditions.

In the case of the Barnes Trust, the deviation doctrine was used to make significant changes to the trust terms, changes that highlight the extent to which deviation can reform a trust using the language of administrative change. ${ }^{200}$ The Barnes Trust was formed by Albert Barnes, a physician and art

195 Commonwealth v. Barnes Found., 159 A.2d 500, 500 (Pa. 1960).

196 RESTATEMENT (THIRD) OF TRUSTS $§ 66(1)$ (2003).

197 UNIF. TRUST CODE $\S 412$ (a) (emphasis added) ("To the extent practicable, the modification must be made in accordance with the settlor's probable intention."). In the comment to this section, the drafters added that " $[t]$ he purpose of the 'equitable deviation' authorized by subsection (a) is not to disregard the settlor's intent but to modify inopportune details to effectuate better the settlor's broader purposes." $I d$. $\mathrm{cmt}$.

198 Johnson, supra note 187, at 354 ("[C]ourts can rather arbitrarily determine ex ante the outcome of a particular dispute or litigation by simply characterizing a proposed change in a trust's operation or management as administrative (calling for the liberal doctrine of deviation) or as substantive (calling for the much narrower doctrine of cy pres).").

199 Id. at 375.

${ }^{200}$ See In re Barnes Foundation, No. 58,788, $2004 \mathrm{WL} 2903655$, at *1 (Pa. Ct. of Common Pleas Dec. 13, 2004). 
collector, on his property in Lower Merion, just outside of Philadelphia. ${ }^{201} \mathrm{He}$ collected primarily French Impressionist and Post-Impressionist pieces, but owned "about two thousand works in all, by artists ranging from El Greco and Rubens to Miró and Modigliani." ${ }^{202}$ As Barry Munitz, the president of the J. Paul Getty Trust, puts it, "[t]here are some of the most spectacular paintings that the world has ever seen." 203 Aside from the quality of the collection, the Barnes collection may be most well known for the restrictions placed on the artwork.

The 1946 bylaws to the trust indenture drafted by Barnes, an adamant (and eccentric) populist, stated that "plain people, that is, men and women who gain their livelihood by daily toil in shops, factories, schools, stores and similar places, shall have free access to the art gallery and the arboretum upon those days when the gallery and the arboretum are to be open to the public."204 Barnes insisted that the "purpose of this gift is democratic and educational in the true meaning of those words, and special privileges are forbidden."205 Accordingly, Barnes prohibited any "society functions commonly designated receptions, tea parties, dinners, banquets, dances, musicales or similar affairs ...." 206 Barnes also prohibited the sale or loan of any of the artworks and specified that "[a]ll paintings shall remain in exactly the places they are at the time of the death of Donor and his said wife."207

When Barnes died in 1951, the legal challenges began almost immediately. The first challenges were not cy pres ones, however: these first lawsuits sought not to change the trust terms, but to enforce them. In 1953, an editorial writer from the Philadelphia Inquirer, with the consent of the Attorney General, sought to compel the alteration of the Barnes' administrative rules allegedly limiting access of public to institution's art gallery. ${ }^{208}$ The plaintiff filed a bill in equity for administrative change: "Appellant's bill does not seek application of the cy pres doctrine because of alleged failure of the trust, but complains of the manner in which the Foundation is being administered as being violative of its corporate purposes." ${ }^{209}$ The court dismissed the complaint for lack of standing. Seven years later, however, the standing question was resolved when the Attorney General acting on his own filed a new petition requesting that the

201 John Nivala, Droit Patrimoine: The Barnes Collection, the Public Interest, and Protecting Our Cultural Inheritance, 55 RUTGERS L. REV. 477, 477-78 (2003).

202 Jeffrey Toobin, Battle for the Barnes, THE NEW YORKER, Jan. 21, 2002, at 34.

${ }^{203} \mathrm{Id}$.

204 Barnes Foundation Bylaws, BARNESWATCH.ORG, http://www.barneswatch.org/main_bylaws.html [http://perma.cc/6AHG-EJTG].

${ }^{205} \mathrm{Id}$.

${ }^{206} \mathrm{Id}$.

207 Id.

${ }^{208}$ Wiegand v. Barnes Found., 97 A.2d 81, 81 (Pa. 1953).

${ }^{209} \mathrm{Id}$. at 84 . The bill was denied by the trial court and appealed to the state supreme court. Id. at 81-82. 
Barnes Foundation allow public access to the artwork "in accordance with the terms of the indenture."210 Because of the trust terms stating that all people were to have free access to the art gallery and because the Foundation was receiving the benefits accorded to a public charity, the court ruled that the collection was obligated to provide public access to the artwork. ${ }^{211}$

Litigation did not end there. The claims that followed, however, sought to modify trust terms. Over the years an "extensive litigation history and the significant expense of maintaining an increasingly valuable collection" caused financial problems for the Barnes Foundation. ${ }^{212}$ Foundation trustees bemoaned "their inability to fundraise because of the limitations on public access, the small size of the board, the inability to deaccession works from the collection, and the constant costs of litigation."213 Moreover, pursuant to the trust terms, the Foundation still did not charge entrance fees to visitors. In 2003, in response to distressed financial circumstances, the trustees filed a petition to restructure the Foundation Board and relocate the collection from Lower Merion to Philadelphia in conjunction with the acceptance of a proposal from the Pew Charitable Trusts and the Lenfest Foundation.214 Pew and Lenfest offered $\$ 150$ million to "ensure the Foundation's long-term financial health," conditioned on the collection's move into Philadelphia. ${ }^{215}$

Specifically, the Foundation trustees requested that the court "remove restrictions in the current [indenture, charter, and bylaws] that prevent relocation of the Foundation's main gallery from the Merion facility to Philadelphia." ${ }^{16}$ They further requested that the court "remove some of the conditions and stipulations set forth in the present Indenture that restrict the Foundation. The Foundation will therefore have the flexibility in the future to manage its affairs in accordance with its best professional and business judgment."217 In making these requests, the trustees also reiterated that "[n]one of the proposed changes would alter the Foundation's existence as an educational institution." 218

210 Commonwealth v. Barnes Found., 159 A.2d 500, 501 (Pa. 1960). The indenture provided that "plain people ... shall have free access to the art gallery and the arboretum upon those days when the gallery and the arboretum are to be open to the public." Instead, the court remarked that "officers and trustees have consistently refused to the public admission to its art gallery." Id. at 502 .

211 Id. at 506.

212 Eisenstein, supra note 112, at 1751.

213 Id. at 1752.

${ }^{214}$ Second Amended Petition of the Barnes Foundation to Amend its Charter and Bylaws at 9, In re Bames Found., No 58,788 (Pa. Ct. of Common Pleas Oct. 21, 2003), http://www.barnesfriends.org/downlload/2nd_amended_petition_barnes.pdf

[http://perma.cc/24YE-LEEE].

$215 \mathrm{Id}$. at 5 .

$216 \mathrm{Id}$. at 9.

217 Id.

$218 I d$. at 10. 
Using the doctrine of deviation, the court granted the Foundation's requests based on the Foundation's financial circumstances. ${ }^{219}$ Addressing the question of relocation and citing to the Restatement (Second) of Trusts, the court stated "that the provision in Dr. Barnes' indenture mandating that the gallery be maintained in Merion was not sacrosanct, and could yield under the "doctrine of deviation,""220 provided that the proposed solution "represented the least drastic modification of the indenture that would accomplish the donor's desired ends." 221 The court did not discuss the applicability of cy pres, and allowed significant changes by deploying the doctrine of deviation. Deviation, however, produced a similar result because, doctrinally, it resembles cy pres in the premise. That is to say, the implied conclusion was that Barnes had a general charitable intent to found a museum and the court therefore struck out the offending terms in the trust in order to carry out this dominant intent. ${ }^{222}$

Opposition to the petition and the resulting decision was immediate and intense. The Board of Commissioners of Lower Merion Township passed a resolution stating that the Barnes Foundation was "part of the fabric, character and culture of Lower Merion Township" and any change in location was "in direct contravention of the intent and purpose of Albert Barnes."223 Some commentators criticized the proposal, calling it "death by disembowelment" 224 and an "act of cultural vandalism." 225 Despite all the turmoil, ${ }^{226}$ over a decade

219 In re Barnes Foundation, No. 58,788, 2004 WL 2903655, at *1 (Pa. Ct. of Common Pleas Dec. 13, 2004).

220 Id.

221 Id. (citation omitted)

222 See generally id.

${ }^{223}$ Lower Merion Board of Commissioners, Resolution of the Board of Commissioners of the Township of Lower Merion, FRIENDS OF THE BARNES Foundation, http://www.barnesfriends.org/downlload/legal_LowerMerionResolution.pdf [http://perma.cc/X64K-4K3A].

224 Robin Pogrebin, A Move Done, Barnes Leader Makes Another, N.Y. TIMES, Dec. 28, 2013, at C1 (quoting Richard Lacayo, We Had to Destroy the Village to Save It, TIME, Mar. $6,2007)$.

${ }^{225}$ Id. (quoting Michael J. Lewis, Art for Sale, CommeNTARY (Mar. 1, 2006), https://www.commentarymagazine.com/article/art-for-sale/ [http://perma.cc/R72N-3ZCQ]).

226 The legal battles did not stop after the 2004 ruling. The group "Friends of the Barnes" filed a petition to reopen the proceedings in 2007. See In re Barnes Foundation, No. 58,788 (Pa. Ct. of Common Pleas May 15, 2008) (mem.), available at http://www.barnesfriends.org/downlload/Memo\%200pinion\%2005-15-08.pdf

[http://perma.cc/4LVL-PWAN]. Although the court dismissed their petition for lack of standing, Friends of the Barnes filed another petition to reopen the case in 2011. In their second petition, Friends of the Barnes again argued that new information about funding had been revealed, this time in the movie "The Art of the Steal." Petition to Reopen the Matter Based on Newly Discovered Evidence of Improper Conduct Not Known During the Time of Trial filed by the Attorney General and the Governor of Pennsylvania, In re Barnes Foundation, No. 58,788 (Pa. Ct. of Common Pleas Feb. 17, 2011), available at 
after the Foundation filed the petition to amend the terms of Barnes's trust indenture, the collection moved to Philadelphia and opened to the public in its new location. The galleries were, according to art commentators, "recreated with amazing fidelity in terms of proportions, window placement and finishings, albeit in a slightly more modern style. The structure is oriented to the south, exactly as in Merion; the same mustard-colored burlap covers the walls; the same plain wood molding outlines doors and baseboards." 227 All the paintings were placed in the same arrangements as in their previous home, and the New York Times art critic raved that "Barnes's exuberant vision of art as a relatively egalitarian aggregate of the fine, the decorative and the functional comes across more clearly, justifying its perpetuation with a new force." 228

Although the doctrine of deviation does not constitute cy pres, the doctrine has nonetheless provided a way for charitable organizations to circumvent the more stringent cy pres requirements. The boundaries between the two doctrines have also blurred, such that the lower threshold required to satisfy the deviation standard may be creating change within cy pres as the two doctrines come to more closely resemble one another. Alex Johnson has proposed that deviation and cy pres doctrines be merged and "treated, for all intents and purposes, as the same. In other words, courts should employ the same test to determine whether to change terms and conditions of so-called administrative or substantive provisions of a charitable trust...."229 Likewise, Ronald Chester has remarked that cy pres may become obsolete because the events that trigger deviation are the same that trigger cy pres. ${ }^{230}$ The use of deviation,

http://www.barnesfriends.org/downlload/Barnes\%20(Petition).pdf $\quad$ [http://perma.cc/CP8FLANN]. The court sustained preliminary objections to the petition. Furthermore, the court imposed sanctions on the petitioners. In re Barnes Foundation, Memorandum Opinion and Order Sur Preliminary Objections to Petitions to Reopen, No. 58,788 (Pa. Ct. of Common Pleas Oct. 6, 2011), available at http://www.barnesfriends.org/downlload/fbf_100611_barnes_opinion_judge_ott.pdf [http://perma.cc/2YDC-YY48].

227 Roberta Smith, A Museum, Reborn, Remains True to Its Old Self, Only Better, N.Y. Times, May 17, 2012, at A1. Other critics disagreed. See Jed Perl, The Barnes Foundation's Disastrous New Home, THE New Republic (Aug. 24, 2012), http://www.newrepublic.com/article/magazine/books-and-arts/106435/barnes-foundationmove-philadelphia-tod-williams-billie-tsien [http://perma.cc/PKT9-KU9T] ("The Barnes Foundation, that grand old curmudgeonly lion of a museum, has been turned into what may be the world's most elegant petting zoo."). Critics point out that an overlooked result of the move is that most of the collection cannot be displayed and there are hundreds of exhibitionquality paintings in the vault.

228 Smith, supra note 227.

229 Johnson, supra note 187, at 354.

230 Ronald Chester, Modification and Termination of Trusts in The 21st Century: The Uniform Trust Code Leads A Quiet Revolution, 35 REAL Prop. ProB. \& TR. J. 697, 709 (2001) ("Events that make continuation of the trust as is impracticable, impossible, illegal or wasteful seem to be just the types of unanticipated circumstances necessary to trigger section 411." (internal quotations omitted)). 
consequently, is an important reform-one that impacts cy pres-and another tool for nonprofit institutions seeking gift modifications.

\section{GIVING GIFTS IN THE CHARITABLE ECONOMY}

Cy pres reform-grounded in modifications to the Uniform Trust Code and the Restatement (Third) of Trusts and making its way into judicial analysishas changed the doctrine. Reforms have decreased the guesswork for courts with respect to donor intent, created room for concepts of economic waste and efficiency, and focused on facilitating the better administration of charitable gifts. Still missing, however, is a theory to explain the nature of charitable property and therefore fully account for the correctness of these reforms.

Anti-dead-hand theory - the idea that posthumous control over property should be subject to restriction for (primarily) efficiency purposes-provides an important rationale for limiting the scope of donor control. Removing value-impairing conditions enables greater alienability of property (particularly in the private trust context) and increases the efficient use of all property and assets held in trust. ${ }^{231}$ Anti-dead-hand policy enables an increase in efficiency because it "is fundamentally a change-of-circumstances doctrine" 232 that explains why gift conditions should not control in all circumstances. What anti-dead-hand theory does not address is the particular nature of charitable gifts and why, fundamentally, charitable trust property should be treated differently than other types of property.

In this Part, I set forth the idea that charitable giving takes place within what I call the charitable gift economy-an economy driven by non-market exchanges and social norms. In the charitable gift economy (a concept derived from both anthropological and economic scholarship) gift giving is a form of exchange that is not merely bilateral, but is embedded in a constellation of culturally relevant relationships. Understanding charitable giving within the gift economy allows us to see why cy pres reforms are a positive step in the right direction. Donors receive multiple social goods in the gift economy during their lifetimes, and this receipt justifies the liberalization of the cy pres doctrine. Once we fully understand what the donor receives in the charitable gift economy, then, we also understand that making deviations beyond a donor's lifetime is as understandable as it is often necessary. The donor, in short, has received her due.

Legal scholars have begun to broach this question by addressing the tax benefits that donors receive. Scholars have suggested that a charitable bargain exists between the donor and the public, mediated through institutions and the

231 See SIMES, supra note 15; Langbein, supra note 15. See also T.P. Gallanis, The Rule Against Perpetuities and the Law Commission's Flawed Philosophy, 59 CAMBRIDGE L.J. 284 (2000) (critiquing Simes). For an overview of dead-hand restraints, see Gregory S. Alexander, The Dead Hand and the Law of Trusts in the Nineteenth Century, 37 STAN. L. REV. 1189, 1261-62 (1985).

${ }^{232}$ Langbein, supra note 15, at 1111. 
government. While this understanding of donor benefits and charitable giving is apt, it is nonetheless incomplete. I begin this Part by explaining the tax intervention and the current reasoning deployed by scholars to justify cy pres liberalization. Subsequently, I discuss charitable giving as part of a complex gift economy and detail the myriad tangible and intangible benefits that donors receive from their giving. Finally, I propose further reforms based on the understanding that the charitable gift economy provides donors with a range of plentiful benefits during their lifetime.

\section{A. The Modern Charitable Bargain}

While the Dartmouth case and its progeny established the charitable gift as an implied contract-an exchange of resources for a perpetual legacy ${ }^{233}$ - the modern charitable bargain is better defined. The major concrete benefit that donors now receive through their charitable giving is preferential tax treatment. ${ }^{234}$ Since the introduction of the charitable deduction in 1917, an individual has been allowed to deduct charitable contributions, subject to certain limitations. ${ }^{235}$ Donors receive a tax deduction on personal income taxes for making charitable gifts, in the form of established trusts, as lifetime gifts, and as bequests. ${ }^{236}$ Donors can deduct up to fifty percent of their annual adjusted gross income in charitable gifts and can also take carryover gift deductions for five years. ${ }^{237}$ This includes gifts made as charitable trusts, for which donors can take a tax deduction at the time the trust is created. ${ }^{238}$

${ }^{233}$ Trs. of Dartmouth Coll. v. Woodward, 17 U.S. (4 Wheat.) 518 (1819).

234 There is a longstanding debate among tax policy scholars about whether the charitable contribution should be classified as a tax "preference" or whether a deduction for charitable contributions instead is necessary to define the income tax base. See William Andrews, Personal Deductions in an Ideal Income Tax, 86 HARV. L. REV. 309, 314 (1972).

235 The deduction is codified at I.R.C. $\$ 170$ (2012). I.R.C. $\$ 170(\mathrm{c})(2)$ defines entities to which deductible contributions may be made. Congress first adopted a contributions deduction in 1917. War Revenue Act, ch. 63, § 1201(2), 40 Stat. 300, 330 (1917).

Until the mid-1950s, the code limited most people to a deduction equal to fifteen percent of their income; this limit rose to thirty percent in 1954 and remained at that level until 1969. Also prior to 1969, individuals whose charitable gifts and income taxes together surpassed ninety percent of their taxable income in eight of the ten preceding years were allowed an unlimited deduction .... Also in 1969 , the general AGI limit rose to its current level of fifty percent.

Miranda Fleischer, Generous to a Fault? Fair Shares and Charitable Giving, 93 MINN. L. ReV. 165, 171-72 (2008); see also Michael J. GRAETZ \& DeboraH H. SCHENK, Federal InCOME TAXation: Principles and POlicies 411 (7th ed. 2013) ("Although Congress provides incentives for individuals to donate significant portions of their income to charities, it does not believe individuals should be permitted to eliminate their tax liability entirely ... $. ")$.

236 See supra note 235 and accompanying text.

${ }^{237}$ See I.R.C. $\$ 170(\mathrm{~b})(1)(\mathrm{A}),(\mathrm{b})(1)(\mathrm{D})(2)$.

${ }^{238}$ See I.R.C. $\S 170(\mathrm{c})(2)$. 
Donors plan their charitable giving strategically through the use of planned giving vehicles--primarily various forms of split-interest trusts-in order to minimize the impact and consequences of the estate tax. ${ }^{239}$ One fundraising strategist has remarked, "[t]ax and financial considerations are very important to [charitable trust donors]" and "[m]arketing materials for the very wealthy should contain tax and financial information." ${ }^{240}$ Following this advice, many institutions emphasize the tax benefits of a donor's charitable gift, especially in the context of charitable trusts and planned giving. ${ }^{241}$

This preferential tax treatment provides a very significant, tangible benefit to donors. Unsurprisingly, numerous studies show that "awareness of tax advantage" is a prominent reason that donors make charitable gifts. ${ }^{242}$ In fact, studies about donor motivation in making charitable contributions reveal that tax benefit is almost always one of the top three reasons donors give major gifts. ${ }^{243}$ Similarly, studies reveal that "[o]ne thing that donors clearly do not want is to see their wealth pass to the government through taxes."244

In light of this major benefit accorded to charitable donors, some scholars highlight the existence of a charitable bargain or contract between the donor and the public. For example, discussing donor tax treatment, Alex Johnson has

${ }^{239}$ The estate tax was enacted in 1916. See Michael J. GraEtz \& IAN Shapiro, DEATH By a Thousand CUTS: The FIght OVER TAXING INHERITED WeALTH (2006) (providing an overview of the estate tax and the current contestation); see also OSTROWER, supra note 20 , at 103-04.

${ }^{240}$ David W. Brown, What Research Tells us About Planned Giving, 9 INT. J. NONPROFIT \& VolunTARY SECTOR MARKETING 86, 93 (2003).

${ }^{241}$ For example, the Museum of Modern Art advertises "planned giving options that have favorable financial and tax benefits." Museum of Modern Art, Ways of Giving, MUSEUM OF MODERN http://www.moma.org/support/support_the_museum/planned_giving/index

[http://perma.cc/M5MA-9NLQ] ; Harvard University likewise touts the tax benefits of establishing a charitable remainder trust. See Planned Giving: Charitable Remainder Trusts, HARVARD UNIV., http://alumni.harvard.edu/ways-to-give/planned-giving/pay-income/crt [http://perma.cc/N6Q6-QV6Y].

${ }^{242}$ Lise Vesterlund, Why Do People Give?, in THE NonProfit SeCtor: A RESEARCH HANDBOOK 568, 569 (Richard Steinberg \& Walter W. Powell eds., 2006). See also Mount, supra note 21 , at 7,12 (concluding that tax incentives may influence the size of the donation).

${ }^{243}$ See Vesterlund, supra note 242 , at 569 ("Data from a survey of 200 big donors are suggestive of the impact that taxes have on giving .... This study revealed that 'awareness of tax advantages' was ranked the third most important motivator for making a charitable donation."). The survey cited is found in Russ alan Prince \& Karen Maru File, The SeVen FaCes of Philanthropy: A New Approach to Cultivating Major Donors 45-46 (1994) ("Investors tend to believe that much, if not all, the monies they give nonprofits would otherwise be diverted to government in the form of taxes. Tax avoidance alone is a powerful motivator to this group, and a significant stimulus to their philanthropic behavior.").

244 OSTROWER, supra note 20, at 101. 
observed that, "by establishing a charitable trust, the settlor has entered into a contract... [that] provides tangible and intangible benefits to the settlor and tangible benefits to society." 245 Similarly adverting to an implied if imperfect bargain between donor and public, another scholar has remarked, "[c]haritable trusts receive enormous benefits from the public, justified by the public nature of the trust itself. The law does not require any proportionality between the benefits - tax exemption, existence in perpetuity, and public enforcement-and actual service to the public." 246 Scholars have therefore adverted to the substantial benefits that donors receive in the form of both preferential tax treatment and exemption from the rule against perpetuities. Furthermore, they have marshaled these facts to support the liberalization of cy pres analysis. The picture, however, remains incomplete.

\section{B. Completing the Picture of Charitable Giving}

To complete the picture, we need to understand charitable giving as situated in a complex gift economy. This requires more than understanding the concept of the charitable bargain to include tax benefits. We must reimagine our conception of gift-giving; it is not solely a bilateral exchange with easilydefinable, material benefits accruing to each party. Rather, gift-giving is a complicated form of exchange that provides a donor with numerous intangible benefits and operates within an intricate system of social networks and cultural norms. Ilana Eisenstein describes this more complete notion of the gift economy, stating that "the donation calculus" includes factors such as "tax incentives, absolute levels of wealth, 'old money' cultural norms, individual morality and altruism, and the desire for social power and prestige." 247 A full theory of this gift economy, however, has yet to be imported into trust law.

Anthropologists and sociologists pioneered the concept of the gift as a form of exchange. Marcel Mauss, in his seminal anthropological study, elucidated how gifts are in fact deployed to create informal contracts, cement social exchanges, and clarify intra-group relationships. ${ }^{248}$ According to Mauss and his followers, gifts are a form of currency and they allow members of certain communities and societies to signal not only appreciation or gratitude, but also kinship, obligation, and even superiority. ${ }^{249}$ Contrasting participants in the gift economies with those in commodity economies, Mauss observes that:

245 Johnson, supra note 187 , at 387 . Other scholars discuss the existence of a charitable bargain but maintain the focus on perpetuity in exchange for gifts. See, e.g., Eason, supra note 114 , at 124 ("Society has thus struck a more conciliatory bargain with donors who contribute their property in furtherance of such public purposes. Societal concessions to charitable donors, in other words, permit these donors to exercise a degree of perpetual control over the use of contributed property in ways otherwise foreclosed by law.").

246 Eisenstein, supra note 112 , at 1786.

247 Id. at 1758-59.

248 See generally MaUSS, supra note 1.

${ }^{249} \mathrm{Id}$. at 6-7. 
[W] hat they exchange is not solely property and wealth, movable and immovable goods, and things economically useful. In particular, such exchanges are acts of politeness: banquets, rituals, military services, women, children, dances, festivals, and fairs, in which economic transaction is only one element, and in which passing on of wealth is only one feature of a much more general and enduring contract. ${ }^{250}$

Economists as well as law and economics scholars have also debated what motivates gift giving and how gift giving constitutes a subtle form of exchange. Eric Posner has observed, with respect to non-charitable gifts, that "a gift to a friend often calls for a return gift on a future occasion, or at least expressions of gratitude; a gift to a business associate frequently creates the expectation of future dealings; and a gift to a politician generally requires the politician to show some favoritism to the donor in return." ${ }^{251}$ Economists have also studied charitable giving, in particular, in an attempt to explain why individuals make charitable gifts when the economic return is absent and any other return is non-obvious. ${ }^{252}$

Sociologists have likewise studied the reasons why donors choose to make charitable gifts. Building on Veblen, who posited that participation in charitable activities constituted a part of conspicuous leisure and signaled social class belonging, ${ }^{253}$ sociologists focus on the nexus of non-economic exchanges in which charitable gifts are embedded and the social norms that govern these exchanges. Francie Ostrower states that " $[\mathrm{g}]$ ift exchange has been interpreted as a symbolic representation of the relationships among the individuals who exchange gifts. Philanthropic gifts are also expressive of relationships, but they express the individual's relationship to, and identification with, particular social groups." ${ }^{254}$ Motivated by the more practical concern of raising money, fundraising experts and leaders have also delved into analyzing which benefits are most attractive to donors with an eye to better design in fundraising programs. ${ }^{255}$ The sections that follow explain exactly how charitable gifts act as a multifaceted form of exchange in a gift economy in which "exchanges and contracts take place in the form of presents." ${ }^{256}$

$250 \mathrm{Id}$.

251 Posner, supra note 18 , at 569.

252 See infra note 261 and accompanying text.

253 See Veblen, supra note 17 , at 59 ("Under the mandatory code of decency, the time and effort of the members of such a household are required to be ostensibly all spent in a performance of conspicuous leisure, in the way of . . charity organisations . ...').

254 OSTROWER, supra note 20, at 98.

255 See generally FrUMKIN, supra note 21. See also Barman, supra note 20, at 1423-24; Mount, supra note 21, at 11-13.

256 MaUss, supra note 1, at 3. For a discussion of how gifts-and bribes-have been treated in the representation of judicial administration, see JUDITH RESNIK \& DENIIS CURTIS, REPRESENTING JUSTICE: INVENTION, CONTROVERSY, AND RIGHTS IN CITY-STATES AND 


\section{Signaling Status and Social Benefit}

In the gift economy that helps govern charitable trusts and gifts, innumerable benefits flow between the donor, the charitable organization, and the public. Furthermore, social groups, the institutional community, and the public at large often mediate the bestowing of these benefits. Outside of preferential tax treatment, donors receive other tangible benefits as well in the form of donor recognition gifts and opportunities. ${ }^{257}$ The tangible benefits a donor may receive include naming opportunities, event invitations, social introductions, and board positions. ${ }^{258}$

Fundraising leaders have learned how to craft a range of giving opportunities that bring tangible benefits, such as the naming of buildings or lecture halls, inclusion on donor walls, and invitations to black-tie events. ${ }^{259}$ Donor relations and stewardship professionals in fundraising offices across the country are charged with making sure that donors are recognized in timely and gift-appropriate ways-whether it be inviting the donor of an endowed chair at a university to lunch with the faculty member who holds the chair, or sending letters from students to the donors who fund their scholarships. ${ }^{260}$ Donors take these benefits seriously. As one economist notes, "the form of recognition the charity will provide in exchange for the gift is often spelled out in legal contracts, and there are even cases where donors have demanded the return of donations after their gifts have not been recognized to their satisfaction."261

\section{DEMOCRATIC COURTROOMS 38-48 (2011).}

${ }^{257}$ Charitable organizations cannot provide tangible benefits that exceed a certain amount in return for their contributions; otherwise, the benefit will impact the tax-deductible status of the gift. See I.R.C. $\S 170(f)(8)(B)(2012)$. The IRS has provided administrative guidelines. See Rev. Proc. 90-12, 1990-1 C.B. 471 (1990).

258 Vesterlund, supra note 242 , at 573 ("[L]arge contributors may have buildings named after them, receive exclusive dinner invites, be invited to have lunch with powerful politicians, and so on. In many instances these goods can be acquired only by making donations to the charity, and one may view part of the motivation for the donation as a mere purchase of the associated 'rewards."'); see also TERESA ODENDAHL, CHARITY BEGINS AT Home: Generosity and Self-Interest Among the Philanthropic Elite 34 (1990) ("Most members of the culture of philanthropy sit on several boards where they have the opportunity to meet, influence, and be praised by fellow philanthropists ...."). Charitable trust donors, who are more likely to be high-end donors, receive a disproportionate amount of benefits such as naming opportunities. Vesterlund, supra note 242, at 573.

259 At least one scholar argues that naming rights should not be valued at zero for tax purposes because the benefit is so significant. See William A. Drennan, Where Generosity and Pride Abide: Charitable Naming Rights, 80 U. CIN. L. REV. 45, 46 (2011) ("This special rule for naming rights [effectively valuing naming rights at zero] creates a significant tax revenue shortfall shouldered by all taxpayers generally, and may have pernicious consequences in the charitable world.").

260 See, e.g., PENELOPE BURK, DONOR-CENTEREd FundRAISING 35-60, 115-36 (2003).

261 William T. Harbaugh, The Prestige Motive for Making Charitable Transfers, 88 AM. ECON. REV. 277, 277 (1998). 
Apart from these concrete benefits, donors of charitable gifts and trusts also receive intangible benefits from their gifts. Charitable gifts perform a signaling function and mark the donors as members of a particular, usually high-status, social class or group. ${ }^{262}$ Ostrower argues that "philanthropy and nonprofits have a special place within the elite that goes beyond the particular services of the organizations. ${ }^{2263}$ That is to say, philanthropic giving is a behavioral norm in the culture of the elite, and charitable gifts do more than support a given organization-they announce group membership. ${ }^{264}$ "Through their philanthropy, wealthy donors come together with one another and sustain a series of organizations that contribute to the social and cultural coherence of upper-class life."265

The material benefits related to giving are therefore only the beginning. "Through charity benefits, board memberships, private events open only to large donors, and related mechanisms, elites carve out a separate world for themselves through philanthropy."266 Charitable giving buys social status and "public prestige." 267 Through charitable giving, donors indicate to their peers as well as outsiders that they belong to a specific reference group and, subsequently, modulate their giving such that it aligns with the norms of their reference group.

The importance of reference groups might explain why fund-raisers often emphasize such social activities as parties, dinners, and reunions: these strengthen such groups. The importance of relative donations within these groups may explain the common practice of having large donors solicit contributions from others in their circle. People should presumably increase their donations after being told that a member of their group has given a large amount, especially after they have just had dinner with him. ${ }^{268}$

Similarly, the listing of donor names-arranged according to giving levels-in annual reports, performance programs, and other fundraising publications helps to both establish and police group norms of giving. Supporting the signaling value of public donor recognition, one study

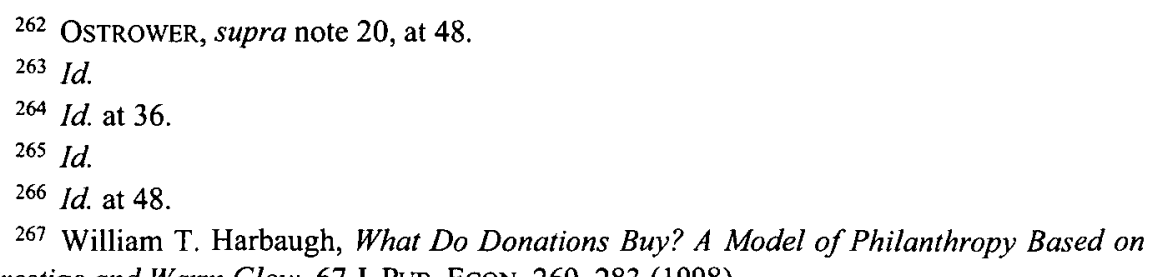
Prestige and Warm Glow, 67 J. PUB. ECON. 269, 283 (1998).

${ }^{268}$ Harbaugh, supra note 261, at 281. See also FRUMKIN, supra note 21, at 258-59 ("In such cases, it is not the needs or demands of beneficiaries that motivate philanthropy, but rather the web of social ties that shape individual charitable behavior and the desire of individuals to be seen as contributing their fair share."); OSTROWER, supra note 20, at 37 ("Donors themselves freely discussed how they 'use' the desire for prestige as a tool in fundraising from their peers."). 
concludes that, "a consumer is more willing to donate to an organization the more likely is the intended audience to hear about that donation... [ [T]his is understandable to the extent that such fund-raising activities publicize the amounts donated by others. Dinners, benefit concerts, and promotional literature can fall into this category." 269 Scholars have termed especially public forms of this behavior "blatant benevolence" and remark that, for all donors, this kind of benevolence is "useful for publicizing one's prosocial nature."270

Confirming the importance of norm creation, Eric Posner states, "if people care sufficiently about their reputations (for being generous or for being wealthy), almost everyone will conform to a norm of gift-giving behavior."271 In another study, economists found that "[i]f the norms about social behavior within the group are violated by some group members not contributing what is considered their appropriate share of contributions to the common interest, this may induce other members of the group to reconsider ...."272 Donor behavior is intimately calibrated to the perceived norms. Charitable gifts exchange wealth for status, resources for recognition, and support for belonging. The complex of relationships established through charitable giving encompasses individuals, institutions, social groups, and the public at large.

Within the target social group, giving also reinforces individual relationships. Charitable gifts are tools that individuals can employ in order to not only maintain networks of contacts, but also to create added advantage and opportunities for themselves and family members. Donors will make a gift or join a board because a friend or colleague is involved with a particular organization; likewise, a donor may buy a table at an event because a friend is receiving an award. ${ }^{273}$ Donors exploit the charitable gift economy in order to build networking opportunities. In fact, one donor in Ostrower's study said, "[i]t's an opportunity to meet some people and do some things, which in my mind is more networking than anything else." 274 Another donor admitted that

${ }^{269}$ Amihai Glazer \& Kai A. Konrad, A Signaling Explanation for Charity, 86 AM. ECON. REV. 1019, 1024-25 (1996).

270 Vladas Griskevicius, Joshua M. Tybur, Jill M. Sundie, Robert B. Cialdini, Geoffrey F. Miller, \& Douglas T. Kenrick, Blatant Benevolence and Conspicuous Consumption: When Romantic Motives Elicit Strategic Costly Signals, 93 J. Personality \& SOC. PsYCH. 85, 87 (2007). The authors also suggest that blatant benevolence may serve romantic matching purposes. Id. ("A mating motive could either lead both women and men to blatantly display benevolence given that helpfulness is a desirable trait to either sex, or it might lead to a boost in blatant benevolence only for women.").

271 Posner, supra note 18, at 576. See also FrUMKIN, supra note 21, at 258 ("[T]he decision of how much to give can also be shaped by the norms for the social groups within which donors find themselves.").

${ }^{272}$ Kai A. Konrad \& Wolfgang Leininger, Self-Enforcing Norms and Efficient NonCooperative Collective Action in the Provision of Public Goods, 146 PUB. CHOICE 501, 517 (2011).

${ }^{273}$ OSTROWER, supra note 20, at 31-34.

274 Id. at 37. See also FRUMKN, supra note 21, at 258 ("Helping may also provide an 
he agreed to head an alumni fundraising drive partly in order to improve his visibility among classmates, "because everybody knows that someone who takes on the chairmanship of a class reunion is prepared to give." 275 For similar reasons, donors make leadership gifts in order to sit on boards, because board membership offers "valuable social and business connections."276

For those individuals seeking entry into an elite social class, charitable giving is also a valuable tool. As Ostrower notes, "[p]restigious nonprofits and charity benefits become the target of 'social climbing' and networking."277 Making a significant gift to the appropriate nonprofits "serves as a symbol of 'having arrived' socially."278 As one donor remarked, "[i]f you move to [X] and you want to be accepted by the OK people, you break your back to get on the board of the museum .... The entrées leading off that board are not to be believed."279 Exploring the phenomenon of charitable giving as a means to social climbing, economists have studied the utility of a common fundraising practice - kicking off a fundraising campaign with the announcement of one or more major gifts from high-profile donors. ${ }^{280}$ The researchers found evidence to suggest that "a contribution-maximizing fundraiser will benefit from first soliciting donors who have a high social ranking, and then announcing their contributions to those of lower ranking."281 Fundraising professionals themselves agreed that the "strategy may work because it enables subsequent donors to associate with the initial donors, [and] ... enables new money to associate with old money."282 The charitable gift economy, therefore, operates along various axes of ambition, and exchanges are made for compound purposes.

\section{Choosing Causes and Individual Self-Definition}

Charitable giving provides further benefit to the donor by affording the donor an opportunity to participate in a project that is personally meaningful and that contributes to her individual sense of self-definition. Charitable giving allows donors to affiliate with specific groups, institutions, and causes, thereby

opportunity to expand one's social network and access new social opportunities. By giving, donors can buy entrée into social groups and communities that have social prestige, political power, or business ties.").

275 OSTROWER, supra note 20 , at 36.

276 Id. at 38 .

277 Id. at 37.

278 Id. See also ODENDAHL, supra note 258 , at 40-41 ("[O]nce a newly rich family turns to philanthropy, its members have a better chance of being accepted into upper-class society.").

279 OSTROWER, supra note 20 , at 38.

${ }^{280}$ Cagri S. Kumru \& Lise Vesterlund, The Effect of Status on Charitable Giving, 12 ASS'N FOR PUB. ECON. THEORY 709, 725 (2010).

281 Id.

282 Id. at 726 . 
signaling their tastes, preferences, and ideals to a broad audience. In other words, "when it comes to explaining how and why people give, differences are rarely a function of differences in financial capital or even moral capital, but rather the intensity of associational capital, which takes the form of social networks and close identification with causes." 283

Charitable giving is by no means a monolithic endeavor, and within the high-prestige world of philanthropy there are numerous opportunities for donors to give and partner with worthy organizations. As Ostrower found in her study, "[d]onors were often quick to note that there are many worthy causes, more than they could possibly support." 284 Given the wide range of possible objects of charity, and that "[t]he sheer range of possibilities is daunting to many donors," 285 it comes as no surprise that "[t]he choice of what to support lies at the heart of defining a strategy for giving." 286 Indeed, "[a]ll philanthropic activity involves a choice about how to join public needs with private commitments in a way that is both beneficial for others and satisfying for the giver." 287 Usha Rodrigues, drawing on social identity theory, has also posited that non-profit organizations "sell" identity in a way that for-profit corporations cannot, thereby allowing for particularly strong individual identity formation through philanthropy. 288

It goes without saying that the "identification that develops between individuals and institutions may have various meanings." 289 The key is that, in most cases, there exists a strong identification between the individual and the institution that she chooses to support. Donors "believe they have a right to choose the causes they wish to support. Their choices reflect their personal interests and concerns." 290 Choices to affiliate with one organization or cause over another are moments of self-definition. The phenomenon of selfdefinition through charitable giving is reinforced by the fact that high-level philanthropic relationships are "ongoing and longlasting."291 These giving

283 FRUMKIN, supra note 21, at 259-60 (emphasis omitted).

284 OSTROWER, supra note 20 , at 33.

285 FRUMKIN, supra note 21, at 147.

286 Id. See also Paul G. Schervish, Inclination, Obligation, and Association: What We Know and What We Need to Learn About Donor Motivation, in CRITICAL ISSUES IN FUND RAISING 137 (Dwight F. Burlingame, ed. 1997) ("[G]enerosity is not a function of income but of the personal and social aspects of associational density, inclination, obligation, and invitation.").

287 FRUMKIN, supra note 21, at 148.

288 Usha Rodrigues, Entity and Identity, 60 EMORY L. J. 1257, 1283 (2011) ("Nonprofits can create and 'sell' a particular kind of identity, one in which an individual may participate as employee, donor, or volunteer.').

289 OSTROWER, supra note 20 , at 35.

$290 \mathrm{Id}$. at 130.

291 Id. at 34. 
relationships are continuous exchanges that build over the years, cultivated by recipient institutions and cemented by the donor's sense of investment.

Gifts to educational institutions are a common way for individuals to signal a specific affiliative identity, as well as family and social history. Individuals donate to specific schools and universities in their capacity as alumni or because a family member attended the institution. ${ }^{292}$ Donors also give to schools because they met their future spouses, friends, and colleagues during their student days. ${ }^{293}$ In fact, "close associations between families and particular schools may lead individual donors to contribute even where their own sense of involvement is weak." ${ }^{294}$ For these reasons, among others, giving to educational institutions is a strong norm among high-wealth donors, sometimes even capturing "the number-one priority in their charitable giving." 295

Educational giving, however, is not the only outlet for self-definition through organizational affiliation. "Whether consciously or not, we can clearly see that donors define the boundaries of philanthropy... in a way that legitimates them in following their own personal preferences."296 Consequently, donors give to cultural institutions in order to signal their appreciation for and understanding of the arts, or in order to be regarded as an expert in a certain field. ${ }^{297}$ Religious organizations are similarly channels for donors to express certain parts of their identities, as are organizations dedicated to causes related to environmentalism, gender, and other specific social issues. Science funding, for example, has become a newly attractive province for major donors who, "from Silicon Valley to Wall Street... seek to reinvent themselves as patrons of social progress through science research." ${ }^{298}$ In addition, health issues are often very personal ones, and donors often contribute significant amounts to particular medical research when a family member suffers from the disease in question. ${ }^{299}$

292 Id. at 87.

293 Id. at 88-89 ("While discussing their reasons for making larger gifts to their schools, some people also spoke of the enduring, personal relationships they formed as students.'). See also Rodrigues, supra note 288, at 1306 ("[W]hen universities market to potential donors-chiefly alumni-social identity becomes highly important. Few organizations in an individual's life shape one's identity as profoundly as one's undergraduate institution.").

294 OSTROWER, supra note 20, at 32.

295 John J. Havens, Mary A. O'Herlihy \& Paul G. Schervish, Charitable Giving: How Much, by Whom, to What, and How, in ThE NONPROfIT SECTOR: A RESEARCH HANDBOOK 558 (Walter W. Powell \& Richard Steinberg, eds., 2006).

296 OSTROWER, supra note 20 , at 131.

297 Id. at 37.

298 William J. Broad, Billionaires With Big Ideas Are Privatizing American Science, N.Y. Times, Mar. 16, 2014, at A1.

299 Devera Pine \& Sally McLain, Research Funding: No Longer Just Government $\begin{array}{lllll}\text { Dollars, } & 17 & \text { P\&S } & \text { J. }\end{array}$ http://www.cumc.columbia.edu/psjournal/archive/archives/jour_v17n2_0020.html 
By creating private foundations, donors seek to clarify their personal identity and vision through what one scholar has called "strategic giving" 300 individuals leveraging charitable giving "to enact their private visions of the public good." 301 Usha Rodrigues has suggested that "[f]oundations are in a sense the epitome of nonprofits serving an identity function," 302 and that there is a "specific kind of prestige associated with creating a nonprofit that fulfills the founders' goals." 303 Even working with preexisting institutions, as sophisticated consumers, "donors have increasingly defined giving styles and engagement strategies that call for close collaboration between themselves and nonprofit organizations." 304 Accordingly, donors approach their charitable giving through the lens of a pre-set "philanthropic agenda" that is based on personal considerations. ${ }^{305}$ Susan Ostrander, describing trends toward increased donor control in gifting, has observed: "The term social entrepreneur is now often used as a substitute for the term philanthropist, and it typifies the authoritative and directive stance of high donor control where donors develop and carry out their own personal social visions through their philanthropy."306

Whether or not donors see themselves as social entrepreneurs, they nonetheless view charitable giving-and the restrictions that they place on gifts - as an opportunity to create a unique imprint on the world around them. Gifts are, in this light, markers not just of status but also of personality. Gifts help donors to craft a public persona, just as they can facilitate individual selfactualization. And in either-or both-cases, these multiple modes of interaction and association between donors and their charitable projects underscore the idea that the donor derives great benefit, in terms of personal satisfaction as well as self-definition, through giving.

[http://perma.cc/T62Z-LPG7] ("In other cases, donors are motivated when they, family members, or close friends are touched in a dramatic way by a disease or condition that needs to be researched and eradicated. 'In general, people give money for research because it hits an emotional spot."'). See also Broad, supra note 298 (describing major gifts to medical research by donors who have experienced personal or family trauma and are seeking medical advancement).

${ }^{300}$ FRUMKIN, supra note 21, at 136.

301 Id.

302 Rodrigues, supra note 288, at 1303.

${ }^{303} \mathrm{Id}$.

${ }^{304}$ FRUMKIN, supra note 21, at 265.

${ }^{305}$ Susan A. Ostrander, The Growth of Donor Control: Revisiting the Social Relations of Philanthropy, 36 NONPROFIT \& VOLUNTARY SECTOR Q. 356, 361 (2007). John Eason has speculated that this type of "entrepreneurial" giving may in fact increase the number of donors who place restrictions on their gifts. See John K. Eason, The Restricted Gift Life Cycle, or What Comes Around Goes Around, 76 FORDHAM L. REV. 693, 704 (2007) ("This trend [imposing specific terms and conditions upon gifts] is in part attributable to the growing number of entrepreneurial donors who are confident in both their views and their ability to effectively guide an organization towards its mission.").

306 Ostrander, supra note 305 , at 362. 


\section{Feeling the "Warm Glow"}

Behavioralists, in economics and other social sciences, have also done research on "warm glow"-their term for the personal pleasure that donors experience as a result of their own charitable giving. ${ }^{307}$ From this perspective, donors give not because of concern for their public personae but because giving makes them feel good about themselves. ${ }^{308}$ Susan Rose Ackerman has observed that: "One explanation for giving is that donors benefit from the act of giving itself... . Donors may value not only the benefits supplied by the organization, but also their own acts of charity." 309 Likewise, economists recognize: "To better explain charitable giving it has been argued that . . there are many benefits that only the contributor experiences." 310

In attempting to explain why people give, especially to charitable causes, economists have concluded that one strong factor for charitable giving is "warm glow." 311 Economists define warm glow as "the sense of agency associated with the act of voluntary giving"312 and classify it as one motive, among others, for charitable giving. Economists generally believe that donors fall somewhere on a spectrum between pure altruism and pure egoism, and that their giving is motivated by a complicated combination of factors: "[c]learly social pressure, guilt, sympathy, or simply a desire for a 'warm glow' may play important roles in the decisions of agents." 313 The middle area of the spectrum is home to what economists call "impure altruism." 314 That is, "Considerable evidence exists indicating that givers are neither pure altruists nor pure egoists. Rather, the evidence suggests that givers are impure altruists, motivated by both altruism and warm glow." 315

307 See, e.g., Susan Rose-Ackerman, Altruism, Nonprofits and Economic Theory, $34 \mathrm{~J}$. OF ECON. LITERATURE 701, 712-13, (1996).

${ }^{308} \mathrm{Id}$. at 712 .

309 Id.

${ }^{310}$ Vesterlund, supra note 242 , at 572.

311 See generally James Andreoni, Impure Altruism and Donations to Public Goods: A Theory of Warm-Glow, 100 ECON. J. 464 (1990) [hereinafter Andreoni, Impure Altruism]; James Andreoni, Privately Provided Public Goods in a Large Economy: The Limits of Altruism, 35 J. PUB. ECON. 57 (1988) (discussing the limitations of viewing altruism as the sole motive for charitable giving); Harbaugh, supra note 267 (arguing that the desire for prestige and feelings of warm glow motivate giving).

312 William T. Harbaugh, Ulrich Mayr, \& Daniel R. Burghart, Neural Responses to Taxation and Voluntary Giving Reveal Motives for Charitable Donations, 316 SCIENCE $1622,1622(2007)$.

${ }^{313}$ Andreoni, Impure Altruism, supra note 311, at 464.

314 Id. at 468 ("Impure altruism . . . assumes that people are not indifferent between these alternatives: all else equal, they prefer the bundle with the most warm glow.").

${ }^{315}$ Heidi Crumpler \& Philip J. Grossman, An Experimental Test of Warm Glow Giving, 92 J. PUB. ECON. 1011, 1012 (2008). 
Studies of impure altruism predict that, "[g]iven the choice, people are assumed to prefer to give directly, that is, they prefer the bundle with the most warm glow." 316 Certain subsequent game experiments have demonstrated that warm glow is a determinative factor in charitable giving: "Our results suggest that warm glow giving exists and is significant. Furthermore, when we compare our findings to those of other studies that examined charitable giving without separating warm glow from altruistic giving, the results suggest that warm glow motivates a substantial proportion of all giving."317 Studies of neural responses have similarly indicated that the "[s]ubjective satisfaction [of the study participant] increased as transfers increased and costs decreased and was higher in the voluntary... than in the mandatory conditions." 318 Approaching the question of warm glow from an organizational perspective, another scholar has suggested that the particularities of the nonprofit form is "bound up with warm glow" 319 in a way that other corporate forms cannot recreate.

None of this is to suggest that altruism plays no part in charitable giving. What is nevertheless evident from this analysis of the myriad motives for charitable giving is that altruism is impure at best. Moreover, it is clear that considerations of status, social identity, and personal satisfaction weigh heavily in a donor's decision to make a charitable gift and, in particular, where and how to direct a gift.

\section{Aligning Cy Pres Reform with the Charitable Gift Economy}

Donors receive a robust set of benefits that encourages us to reconceive the transaction between donor and institution based on a more complete understanding of the extended gift economy in which charitable giving takes place. The charitable gift economy is an elaborate economy organized around personal favors, social norms, institutional access, public prestige, and elite status. We must recalibrate how we think of the charitable giving accordingly.

$\mathrm{Cy}$ pres reform and the liberalization of cy pres doctrine harmonizes with this recalibrated understanding of charitable giving as squarely situated in a complex gift economy. From this perspective, cy pres reform is based on the idea that donors receive sufficient benefits during their lifetimes such that perpetual adherence to donor intent is neither necessary nor appropriate. That is to say, perpetual adherence to donor intent is no longer the only, or even the primary, benefit that flows to donors. Historically, this privileging of donor

316 Andreoni, Impure Altruism, supra note 311 , at 470.

317 Crumpler \& Grossman, supra note 315, at 1018. See also Thomas R. Palfrey \& Jeffrey E. Prisbrey, Anomalous Behavior in Public Goods Experiments: How Much and Why?, 87 AM. ECON. REV. 829, 842 (1997) ("We found that altruism played little or no role at all in the individual's decision and, on the other hand, warm-glow effects and random error played both important and significant roles.").

318 Harbaugh et al., supra note 312 , at 1623.

319 Rodrigues, supra note 288 , at 1288. 
intent may have been more appropriate than it is today. However, with the recognition, not only of the tax advantages, but also of the wealth of social and psychological benefits donors receive, there is ample reason to discount the controlling value of donor intent. The doctrinal changes and reforms discussed in the cases in Part II are therefore not only normatively desirable but also theoretically sound.

In fact, based on this understanding of the charitable gift economy, further reform may be appropriate. In this vein, I propose an additional reform-that donor control be time-limited in order to reflect and properly weigh the presence of major donor benefits. The real question, in this new economy, is how much benefit the donor receives for her charitable giving. As the value of the lifetime benefits increase, the sway of donor intent after a donor's death should decrease. A theoretically accurate way to go about answering this question - one which I do not propose here-would be for courts to analyze exactly what benefits a donor received in order to better understand how much weight donor intention should receive. Courts could examine whether the donor received naming rights, participated on a board as a result of a gift, established new institutional relationships, or otherwise benefitted from the gift. This approach, however, would be difficult to realize. These kinds of factsensitive inquiries into the benefits the donor received would be exceedingly burdensome for courts. Furthermore, these inquiries would require the almost impossible quantification of numerous intangibles. How, for example, would a court calculate the value of any reputational enhancement, prestige value, or personal satisfaction received from making a charitable gift?

An alternate approach, one that would be easier to implement, would be to set time limits on donor control of a restricted gift. Time limits help courts avoid difficult questions about the valuation of benefits while still acknowledging the force of the charitable gift economy. Time limits, especially those indexed to the death of the donor, operate on the understanding that numerous donor benefits accrue to the donor during her lifetime, when the donor has the opportunity to enjoy them. Consequently, because the donor has enjoyed the rewards of charitable giving while alive, after her death the benefit of the gift should shift to the institution and larger community that the gift is meant to support. A time-based approach recognizes that, "[a]s the warm glow that originally accompanied a donor's charitable gift begins to fade with time, however, the circumstances and opportunities for public benefit that framed that gift also inevitably evolve." ${ }^{320}$ Moreover, Rob Atkinson has stated: "The moral force of commitments may also diminish over time... Beyond a point, the value to a donor (charitable or otherwise) of controlling the future probably diminishes to the verge of vanishing." 321

Previous proposals for reform have explicitly called for time limits of various kinds. Lewis Simes, in his seminal 1955 lectures about "Public Policy

\footnotetext{
320 Eason, supra note 114, at 124.

321 Atkinson, supra note 12, at 1132.
} 
and the Dead Hand," proposed that "[a]fter the expiration of a fixed time, say thirty years, or earlier with the approval of the trustees and of the donor, if living, a broadened cy pres should be applicable." 322 At the end of the thirty years, courts would presume general charitable intent and interpret restrictions broadly. ${ }^{323}$ Alex Johnson has proposed a revivification of the Rule Against Perpetuities in order to limit the duration of donor restrictions on gifts. ${ }^{324}$ While the charitable trust could exist in perpetuity, the restrictions would be subject to the time limitations embodied by the Rule Against Perpetuities. ${ }^{325}$ After the expiration of the time period, the assets in the trust would be "delivered to an entity for disposition, and that entity will have power to dispose of the assets without any compliance or adherence to the settlor's wishes."326

Iris Goodwin, in her discussion of the Princeton case, has also noted the importance of time periods. ${ }^{327}$ She has suggested that " $[t]$ he administration of a restricted gift should be governed by a succession of 'Program Periods'.. . [of] a length sufficient to allow the charity to steward the grant with a degree of autonomy and also to gather evidence demonstrating the feasibility of the stipulated mission given present circumstances." 328 Goodwin recommends that fifteen years might be an appropriate "program period," and that during the first period "the charity would be required to adhere to the strict terms of the grant." 329 After that period, the charity would be allowed to proceed with greater latitude in interpreting gift restrictions. ${ }^{330}$ These administrative procedures would help "address the burdens of time." 331 Similarly, John Eason has written about the "restricted gift life cycle," adverting to the idea that the obligations that accompany the management of restricted gifts change over time. ${ }^{332}$

322 Simes, supra note 15, at 139.

${ }^{323}$ Id. ("Under this doctrine a general charitable purpose need not be found. It would always be implied in law that the gift was "for charity."').

324 See Johnson, supra note 187, at 383-84 ("The operation of the Rule Against Perpetuities insures that, at least with respect to non-charitable trusts, the settlor's wishes will be adhered to, and to the letter, for a limited period of time.").

325 Id.

326 Id.

327 See Iris J. Goodwin, Ask Not What Your Charity Can Do For You: Robertson v. Princeton Provides Liberal-Democratic Insights into the Dilemma of Cy Pres Reform, 51 ARIZ. L. REV. 75, 123 (2009).

328 Id.

$329 \mathrm{Id}$

330 See id.

$331 \mathrm{Id}$.

332 Eason, supra note 305, at 697 ("[C]onsiderations bearing upon the donor-recipient relationship at any given time will acquire added significance as the seemingly isolated actions inspired by those considerations reverberate throughout the period spanning from inception of the gift to its potential restructuring over time."). 
Building on these proposals, I suggest a similar kind of timeline. To begin, donor restrictions should be supported during the donor's lifetime. Donors should be able to enjoy the benefits that accrue to them while they are alive and still able to appreciate the full extent of any social and psychological aftereffects of giving. Moreover, requests to change gift restrictions due to changed circumstances could be addressed in consultation with the donor. In these cases, cy pres would not even be necessary. In cases where communication with the donor was not possible, courts could evaluate cy pres petitions according to the reformed standards discussed previously. That is to say, a court engaging in cy pres analysis wouldbroadly interpret the requirement that the terms be "illegal, impractical, impossible or wasteful" and presume a general charitable intent.

The death of the donor would be a touchstone event and mark a bright line with respect to donor conditions. I would, in fact, suggest that this event should all but extinguish the need for judicial adherence to donor restrictions. The donor, up until that point, will have received the full benefit of her gift; after that point, the benefit should flow, accordingly, to the institution and the public. Thanks to her gift, the donor has benefitted tax-wise, through the acquisition of social status, and by generating feelings of self-satisfaction. Upon her death, the balance should shift and courts should consider the public benefit rather than the donor's benefit.

In concrete terms, this would mean an even more liberalized cy pres procedure. Doctrinal modification could entail creating a presumption that gift restrictions, in this context, met the criteria of "illegal, impractical, impossible or wasteful." Alternately, reform might entail dropping that requirement altogether, akin to deviation. Further amendments to the doctrine might also entail dropping the requirement of general charitable intent out of judicial analysis so that courts would not be required to address this question and the parties would not be required to expend resources trying to prove or disprove general charitable intent. The most radical reform would be to eliminate the need for either cy pres or deviation petitions and allow trustees and directors to spend the gift money according to institutional need without any judicial intervention. This last type of reform would be most appropriate after the passage of a certain time period, such as fifty years, when the donor's spouse and immediate family would likely no longer be alive as well.

To be sure, there are drawbacks to such a timeline and such reform. The most salient critique is that such a decrease in adherence to donor intent will lead to a related decrease in charitable giving. Commentators fear that "disregarding donor intent will have an adverse effect on charitable giving; once donors know their intentions can be disregarded without legal penalty, they will be less inclined to give." ${ }^{333}$ Moreover, commentators have speculated

333 Atkinson, supra note 12, at 1121. Responding to this point, John Simon remarked in relation to the Buck Trust challenge, "past experience points away from a chilling effect on gifts." In fact, Simon noted, "giving in England actually increased following cy pres 
that by failing to uphold donor terms and intent, courts may remove incentives not only to philanthropy, but also to productivity. ${ }^{334}$ It is more likely, however, that the myriad benefits that donors receive during their lifetime-including a range of financial, social, and psychological benefits-make giving an attractive proposition even in the absence of perpetual adherence to the donor's conditions. Charitable giving is an estate planning strategy, a social norm, a tool for shaping personal identity, and a moment of pleasure. The force of these tokens of the charitable gift economy overrides any danger associated with the removal of one particular motivation to give.

\section{CONCLUSION}

When Chief Justice Marshall wrote, almost two centuries ago, that "one great inducement to these gifts is the conviction felt by the giver, that the disposition he makes of them is immutable," 335 the philanthropic landscape differed significantly from the modern one. Donors did not make charitable gifts as part of a larger strategy to minimize tax burdens or engage in estate planning. Donors were not wooed by sophisticated fundraising professionals with a full menu of donor benefits and donor recognition mechanisms. Moreover, donors were not rewarded to the same degree that they are now with board memberships, leadership volunteer opportunities, or strategic institutional partnerships. Donor intent, consequently, predominated as both the inducement and reward for charitable giving.

More recently, cy pres reform has slowly but steadily chipped away at the primacy of donor intent and made it easier for institutions to reform restricted gifts through judicial intervention. Changes adopted by the Uniform Trust Code, the Restatement, and the Uniform Prudent Management of Institutional Funds Act have modernized cy pres procedure by shifting the presumption in favor of general charitable intent, adding "wasteful" as a criterion, and blurring the line between cy pres and deviation. These reforms represent positive change. What has been missing, however, is a theory based on the intrinsic qualities of charitable gifts to fully support these and future reforms.

Scholars have made inroads on this question by emphasizing the preferential tax treatment that donors receive and how these benefits should shape our understanding of charitable property. Nevertheless, until we understand charitable giving as embedded and operational within a gift economy, fueled by social exchanges and regulated by cultural norms, we will not be able to get at the true extent of benefits flowing to donors. More specifically, we will not recognize the significant intangible benefits donors receive in exchange for

developments that were much more unsettling to donors than any message the Buck Trust case could send." Simon, supra note 167, at 662-63.

334 Macey, supra note 109, at 297 ("'[R]egulating how a settlor can dispose of his wealth may lead to inefficiencies because such interference would decrease the incentives to accumulate wealth.").

335 Trs. of Dartmouth Coll. v. Woodward, 17 U.S. (4 Wheat.) 518, 647 (1819). 
their charitable gifts, including increased social prestige, opportunities for social identity creation, and a strong sense of self-satisfaction. Adopting the charitable gift economy concept into our understanding of trust principles will promote a more modern and nuanced legal view of both philanthropy and charitable gifts. The concept of the charitable gift economy helps us to better imagine the nature and intrinsic value of charitable gifts by uncovering the multiple meanings that constitute gift property. Working on this understanding of charitable giving, courts will be equipped to both support cy pres reform and recalibrate the balance between donor and public benefit. 
BOSTON UNIVERSITY LAW REVIEW 